УДК 94(477-25):2-523

\title{
Вадим Лук'янченко
}

Заслужений архітектор Украӥни

\section{ДЕЯКІ НЕВІДОМІ ФАКТИ ЕВОЛЮЦІї ОБОРОННИХ СПОРУД ВЕРХНЬОЇ ЛАВРИ}

Дослідження оборонних споруд Києво-Печерської лаври охоплюють багато важливих аспектів, що вимагають серйозних архітектурних, археологічних та бібліографічних досліджень. Серед них є питання про етапи їх спорудження та будівельну еволюиію. У статті висуваються припущення про початкове функиіональне призначення приміщень Південної башти (Годинникової), Онуфріївської башти та башти Івана Кушника не тільки для стрільби з рушниць під час бойових дій а й для проживання караулу.

Вперше подано реконструкиї деяких ділянок монастирських мурів Верхньої Лаври та башти Кушника на початковий будівельний період.

Ключові слова: Києво-Печерська лавра, монастирські мури.

1 Зображення Києво-Печерської лаври 3 книги Атанасія Кальнофойського «Тератургіма», що була надрукована у 1638 році.

2 Літопис Руський за Іпатіївським списком. (1989). Пер. Л. Махновець. Київ: Дніпро; Козюба, В. К. (2012). Давньоруське «столпие» за історико-лексичними та археологічними матеріалами. Археологія. 2, 42.; Раппопорт, П. А. (1956). Очерки по истории Русского военного зодчества X-XIII вв. Москва: Издательство Академии наук СССР, 120, рис. 90.
$\mathrm{C}$ тіни і вежі Києво-Печерського монастиря, побудовані коштом I. С. Мазепи, 1698-1701 рр., які збереглися до сьогодні, мали захищати верхню територію монастирського подвір'я, перетворивши його на укріплену фортецю.

Відомо ${ }^{1}$, цо до 1698 року верхню територію Києво-Печерської лаври захищали дерев'яні або дерево-земляні стіни. Заміна їх на нові, цегляні, сталася не відразу. У ті буремні часи не можна було залишати монастир без захисту на тривалий час. Тобто, розібрати існуючі стіни, а потім на їхньому місті будувати нові було $б$ неприйнятним рішенням. Модернізацію захисту у ті часи виконували за рахунок спорудження нового зовнішнього кола оборони. Після завершення його будівництва внутрішнє коло назавжди демонтували. Саме така послідовність еволюції оборонних стін викликала наявність курдонеру біля Троїцької надбрамної церкви.

Щоб зрозуміти, чому так сталося, треба уважно роздивитися гравюру з книги Атанасія Кальнофойського «Тератургіма», що була надрукована у 1638 році. На гравюрі (Іл. 1) бачимо верхню територію монастиря, яка огороджена дерево-земляними стінами, які можливо, не відрізнялися від літописного стовп'я². На територію монастиря можна було потрапити через два в’їзди: східний i західний. Східний в 'їзд - це звичайні дерев'яні двостулкові ворота, а західний - цегляна Троїцька церква.

А тепер уявімо, що нам потрібно побудувати нові оборонні стіни 3 цегли, а старі стіни до завершення будівництва руйнувати не можна. Відступивши на якусь відстань від існуючої дере- 
Iл.1. Фрагмент гравюри А. Кальнофойського.

Іл.2. Головний фасад Троїцької надбрамної церкви та оборонні мури, які разом утворюють Фото 50x років ХХст.
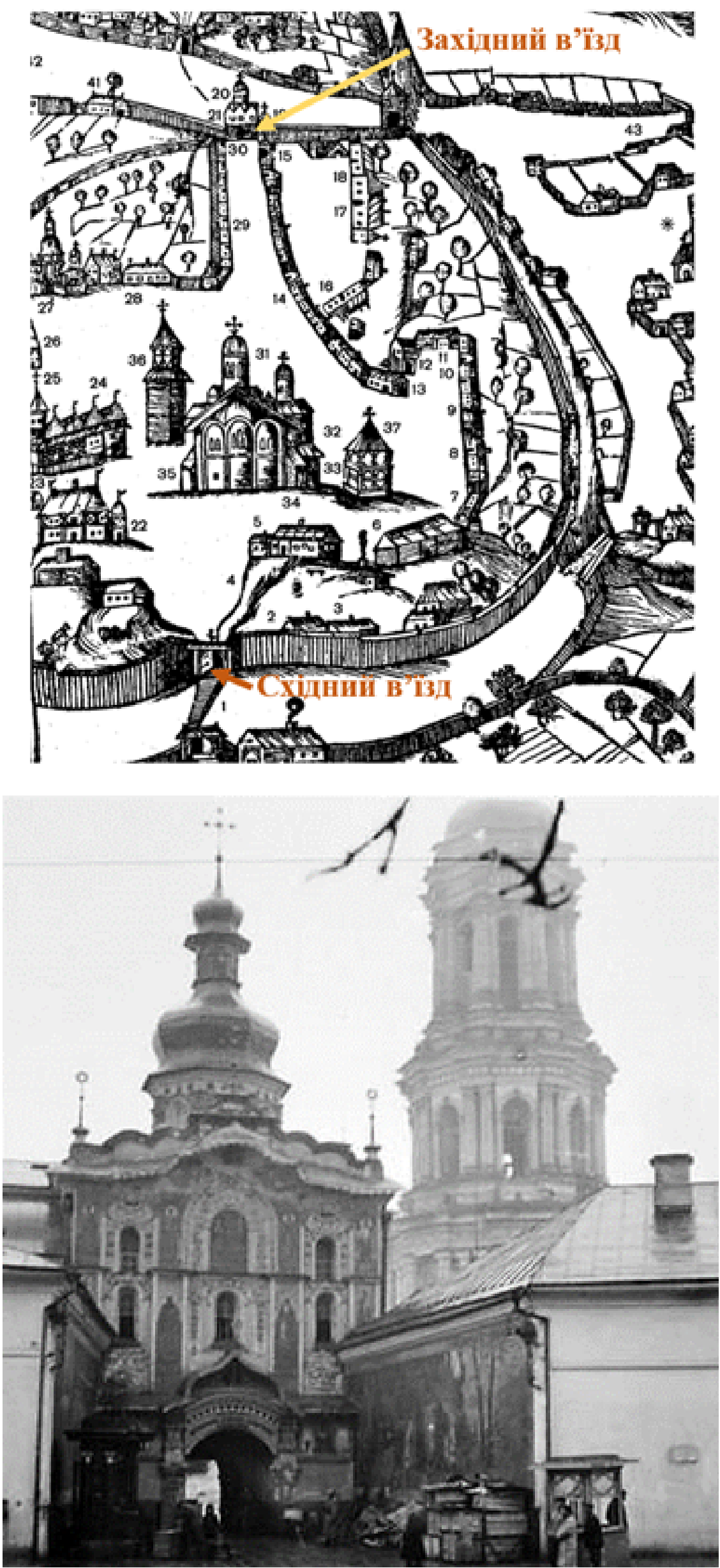
${ }^{3}$ Курдонер - парадний двір, утворений головним корпусом i бічними крилами, які виступають по обидва боки

${ }^{4}$ Крайня, О. О. (2017). Вплив мілітаризації суспільства на життя Церкви в Україні (аналіз документів з історії Києво-Печерської лаври 2-ї половини XVII-XVIII ст.). Церква - наука - суспільство: питання взаємодії. Матеріали П'ятнадцятої Міжнародної наукової конференції (29 травня - 3 червня 2016 р). Київ, С. 19.

${ }^{5}$ Памятники градостроительства и архитектуры Украинской ССР. Т. 1. Киев, Киевская область. (1983). Київ: Будівельник, С. 58.
Іл.3. План - схема умовного маркування ділянок монастирських мурів Верхньої Лаври во-земляні стіни «у бік поля» будуємо цегляні брами (Економічну, Онуфріївську, Південну). Після цього по обидва боки до них прибудовуємо нові оборонні мури і обходимо ззовні по всьому периметру існуючу дерево-земляну стіну. Біля Троїцької надбрамної церкви ми не можемо побудувати нові стіни підходячи з обох боків до брами не зруйнувавши існуючу оборонну стіну. Тому, у даному випадку, єдиний вихід - примкнути новими стінами до головного фасаду Троїцької надбрамної вежі, утворивши курдонер ${ }^{3}$ (Іл. 2).

Таким чином, курдонер існує тільки біля Троїцької церкви, біля інших в'їздів його немає (Іл. 3). На початку XVII ст. Печерський монастир знаходився далеко за межами міста і розширення його у такий спосіб не мало викликати земельних суперечок. Можливо, ця земля на той час вже належала монастирю. Проте, відомо: «У 1674 р. київський воєвода, князь Юрій Петрович Трубецькій писав царю про необхідність укріплення Києва... Для прискорення розбудови фортеці був поповнений склад чужоземних фахівиів-фортифікаторів. Керівником робіт у 1678 р. призначено генерал-майора Патрика Гордона» ${ }^{4}$ У цій цитаті мова іде про спорудження фортеці в Києві на Подолі. Бо оборонні мури Києво-Печерської лаври будувалися пізніше, у 1698-1701 pp. Але, імовірно, що розширення території Верхньої Лаври під цегляні оборонні мури відбувалося теж за наказом царя і тому земельні суперечки не виникали.

Підчас комплексних наукових досліджень, які відбувалися на протязі 24 років, починаючи 31980 р. Спасо-Преображенського монастиря у Новгород-Сіверську, нами було з'ясовано, що розширення і його території підчас реконструкції оборонних мурів відбувалося саме так, як було зазначено вище.

У всі часи до оборонних мурів міст, фортець і монастирів прибудовували різні житлові або господарчі споруди. При цьому спо-

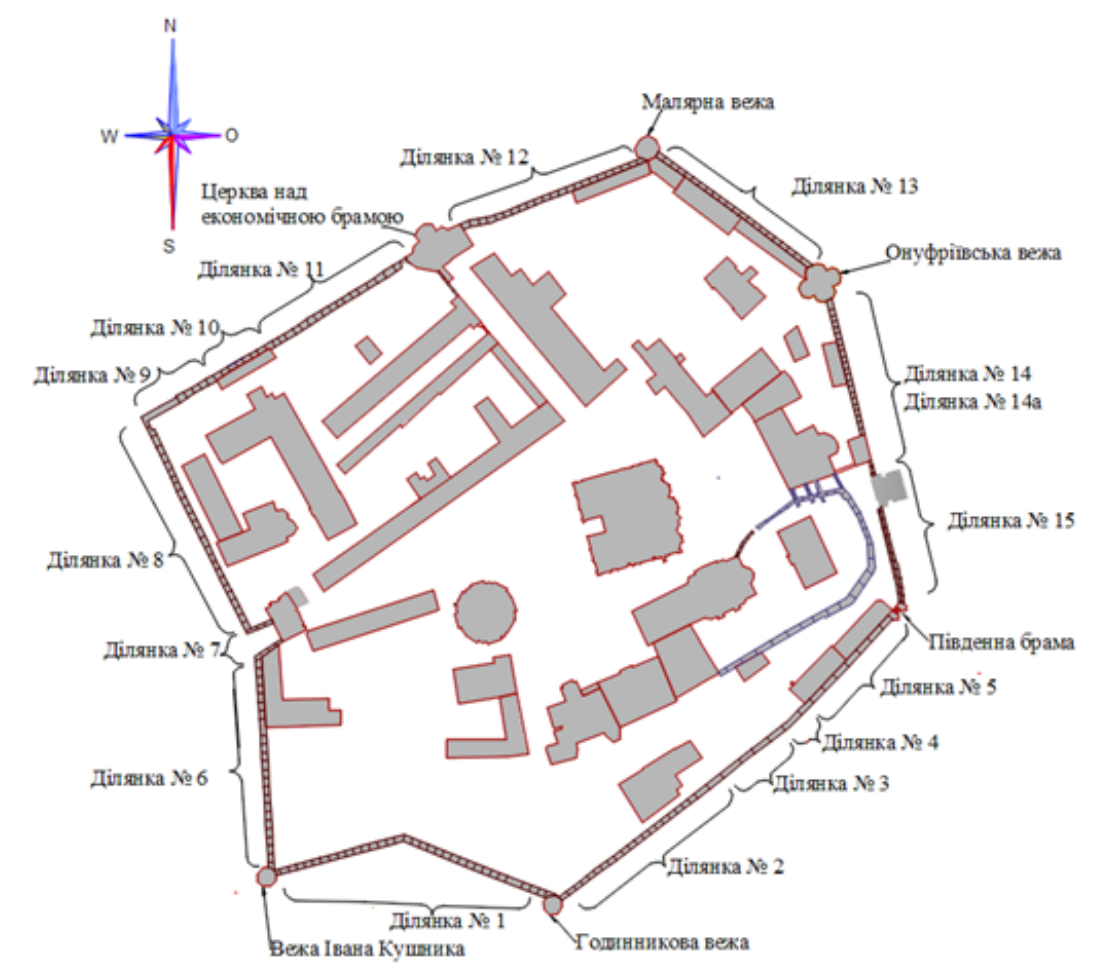


руди прибудовувалися, як правило, з внутрішнього боку оборонних мурів, проте інколи прибудови робилися зовні. Насамперед, це мало місце у випадках, коли оборонні мури втрачали своє функціональне призначення і використовувалися виключно як огорожа. Нове будівництво впритул до існуючих міцних мурів було економічно обгрунтоване тому, що будівельники вже мали одну стіну 3 чотирьох можливих та ще й значно економили площу всередині кола споруд фортеці (замку, монастиря, міста). 3 часом ці прибудови могли бути зруйновані, знищені пожежами, перебудовані або розібрані тому, що в них відпала потреба.

Існує 12 двоповерхових цегляних прибудов до оборонних мурів Верхньої Лаври. Вони були зведені в різний час: більшість у XIX ст. (корпуси $6,10,14,15,16,18,23,34,35,100)$, деякі у XX ст. (прибудова $з$ зовнішнього боку до Часової вежі та книжковий магазин з кафе на ділянці муру №5). Насправді прибудов було набагато більше, але вони не збереглися.

Щодо власне оборонних стін, то вони продовжують існувати, змінивши тільки своє функціональне призначення. Сказати, що ці оборонні мури лишалися незмінними, не можна тому, що після кожної прибудови в їх масиві залишалися гнізда, штраби від нових конструкцій, перекладки мурування (Іл. 4) та інше.

Але іноді прибудови виконувалися одночасно зі спорудженням оборонних стін та веж, і були їх невід'ємною частиною. Йдеться про монастирі, де стіни і башти будувалися як оборонні споруди. Стіни і вежі Троїцького та Єлецького монастирів в Чернігові, що збереглися, не мають жодних оборонних рис, тому, що споруджувалися вони тільки $з$ метою огородження певної території. Їх архітектура несе виключно художньо-декоративне навантаження (Іл. 5-6) з підкресленням майнового статусу ії власника (церкви).

Нові стіни і вежі Києво-Печерського монастиря, мали захищати верхню територію монастирського подвір'я, перетворивши його на цитадель Київської фортеці.

Товщина цих стін (Іл. 7) в нижній їх частині дорівнює 2,5-3 м. Їх висота різна (в залежності від рельєфу місцевості - 6-11 м). 3 внутрішнього боку по всьому периметру стін на широкому виступі кладки, що мав вигляд аркади, розміщувалася бойова дерев'яна галерея і бійниці для стрільби з рушниць. Стіна та бойова галерея були вкриті дахом з гонтовим покриттям.

Не треба забувати, що оборонні стіни самі по собі ворога не зупинять. Для їх захисту потрібен гарнізон. Звичайно, чисельність гарнізону могла змінюватися в залежності від потенційної загрози ззовні. Проте, незалежно від чисельності, для забезпечення боєздатності гарнізону потрібне тепле житло, провіант, туалет та лазня. Не всім відомо, що гарнізон цілодобово охороняє свою територію не у повному складі. Це робить його невелика частина, яка має назву караул. Кожен караул має своє тепле караульне приміщення, розташоване поблизу ділянки, яку він охороняє.

Як приклад наукового відтворення втрачених початкових караульних приміщень, що входили до складу цегляних оборонних споруд у вигляді дерев' яних конструкцій з брусу, можна розгляну- 


\section{РАННЬOMOдеРHE MІсто}

Іл. 4. Фрагмент ділянки №11 монастирських мурів, де проводилися

архітектурно-археологічні дослідження у 2015 році.

Вигляд з боку господарського двору. Дві менші арочні ніші на

першому ярусі монастирських мурів - місце, де з 1933 до 1959 рр. існувала двоповерхова споруда

Iл. 5. Мури Троїцького монастиря в Чернігові після реставрації.

Загальний вигляд із зовні

Iл. 6. Мури Слецького монастиря

в Чернігові після консерваційних робіт
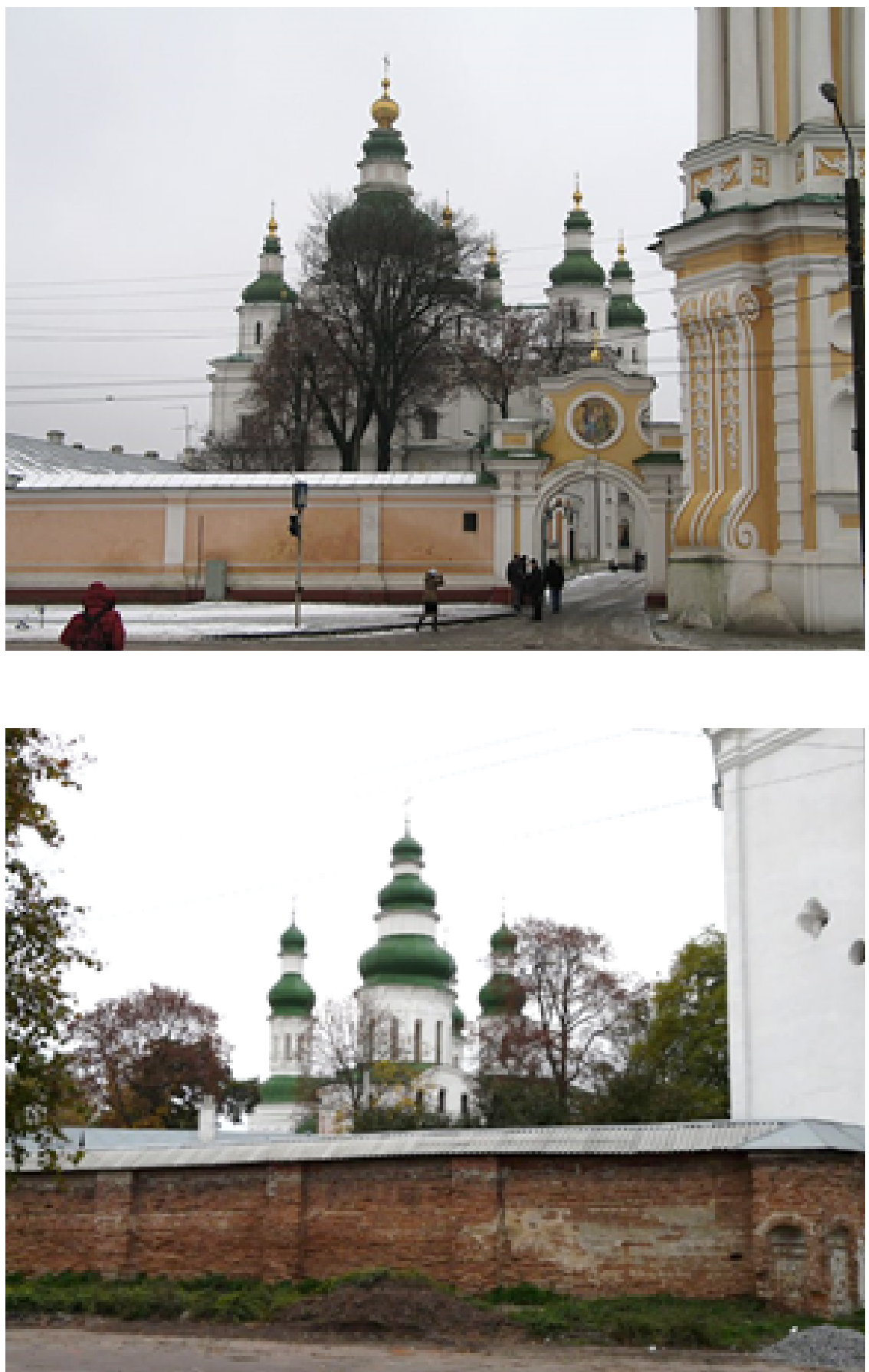
Іл. 7. Фрагмент ділянки №12 монастирських мурів Києво-Печерської лаври після реставрації. Вигляд з боку монастирського подвір'я
${ }^{6}$ Так само, 60.

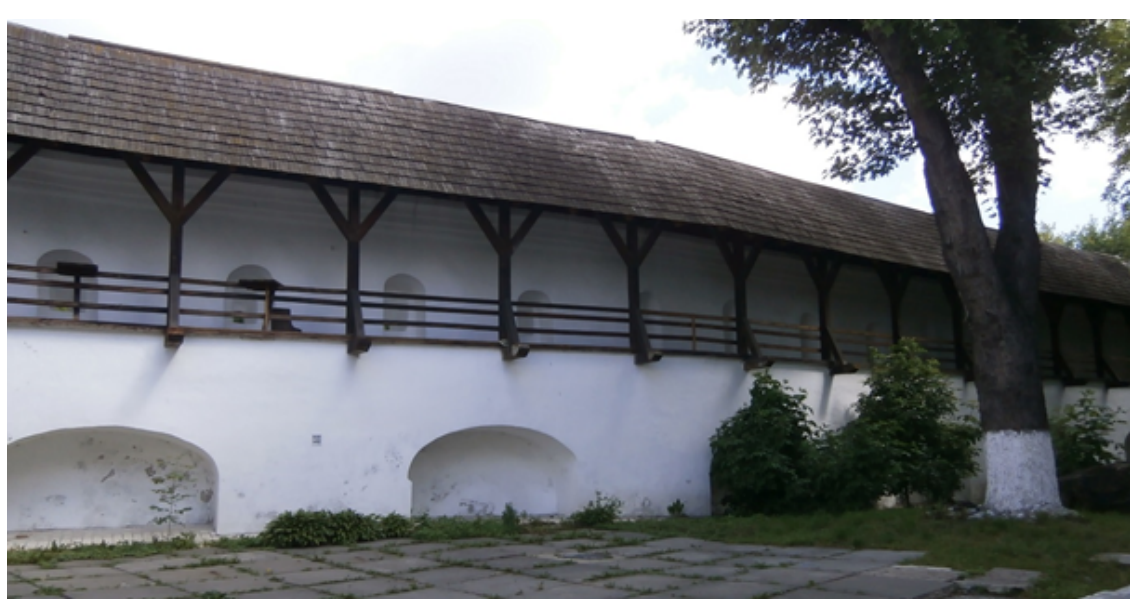

ти деякі пам'ятки Спасо-Преображенського монастиря у Новгороді-Сіверському, відреставровані у 1996 р.(Іл. 8,9).

Іноді у монастирях як караульні приміщення використовувалися вежі, що стояли на зламах оборонних мурів. Приміщення монастирських веж завжди опалювалися, у баштах навіть облаштовували спальні місця і обов'язково туалети (Іл. 10,11).

Нині здається дивним те, що фекалії скидалися під стіни споруди, а для часів середньовіччя це було нормальним явищем. Сміття і нечистоти мали бути лише винесені за межі власної території. Площі, які перебували у спільному користуванні громади, наприклад, дороги і вулиці, не бралися до уваги (Іл. 12,13).

Деякі башти Києво-Печерської лаври теж початково використовувалися як караульні приміщення і мали всі необхідні атрибути: опалення, спальні місця і туалети. Все це існувало до того часу, поки ці споруди не втратили свого оборонного значення.

На Іл. 14,15,16 позначені початкові дверні прорізи, які знаходяться майже впритул до оборонних веж. На сьогодні ці прорізи закладено цеглою, і виглядають вони як звичайні ніші. Про той факт, що це саме дверні прорізи, свідчить їх місце розташування та інші габарити порівняно з габаритами ніш, де влаштовано бійниці для стрільби з рушниць. Припущення про те, що ці двері слугували для виходу на зовнішню дерев'яну обхідну бойову галерею, можна відкинути з двох причин: по-перше, в оборонних стінах немає дверних прорізів з іншого боку башт; по-друге, якби галереї справді існували, то їхнє огородження заважало б вести рушничну стрілянину з бійниць другого ярусу башт.

У вежах Києво-Печерської лаври, імовірно, теплим був тільки другий ярус, де розміщувався караул. Для захисту стін використовувалися перший і другий яруси. «B первом ярусе (башни Ивана Кушника) размещались амбразуры для пушек, во втором - бойниць для ружей». ${ }^{6}$

Твердження про використання гармат на першому ярусі башти (Iл. 17), на мій погляд - хибне. Гармати XVII - XVIII ст. мали великі габарити (Іл. 18). Гармати для захисту фортець, як правило, мали ще більші розміри. «Слід зробити застереження, щзо чітко визначеного поняття «фортечна артилерія» (спеціально технологічно пристосована для оборони фортифікащій) в останній чверті XVII й на початку XVIII cm. у Pосї̈, та й узагалі в Свро- 


\section{РАНHЬOMOдеPHE MICTO}

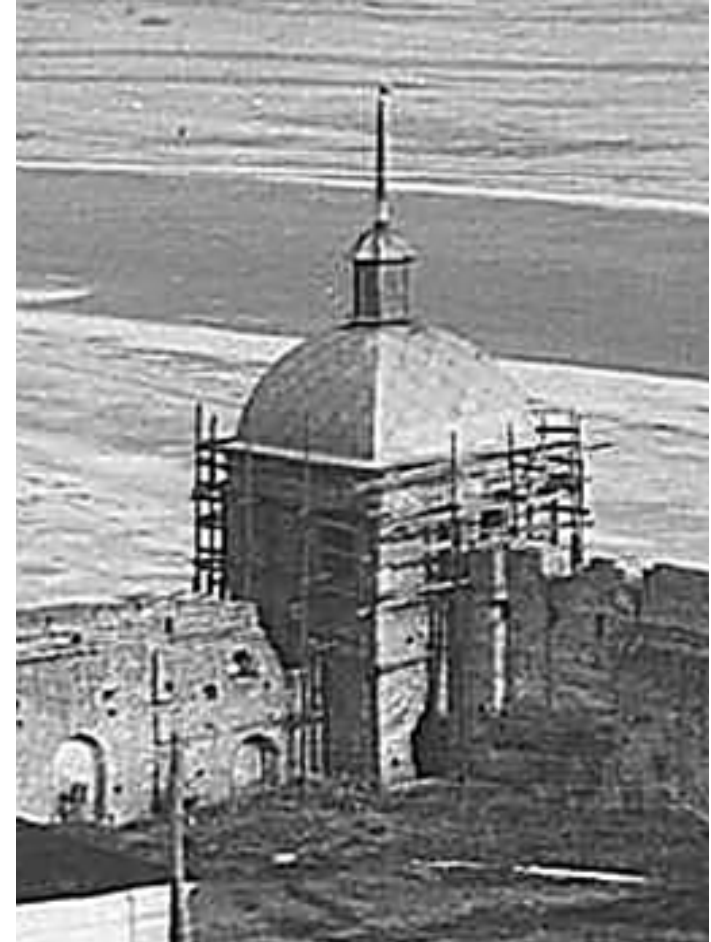

Іл. 8. Північна вежа Спасо-Преображенського монастиря у Новгороді-Сіверському на початок архітектурних натурних досліджень. Січень 1984 р.

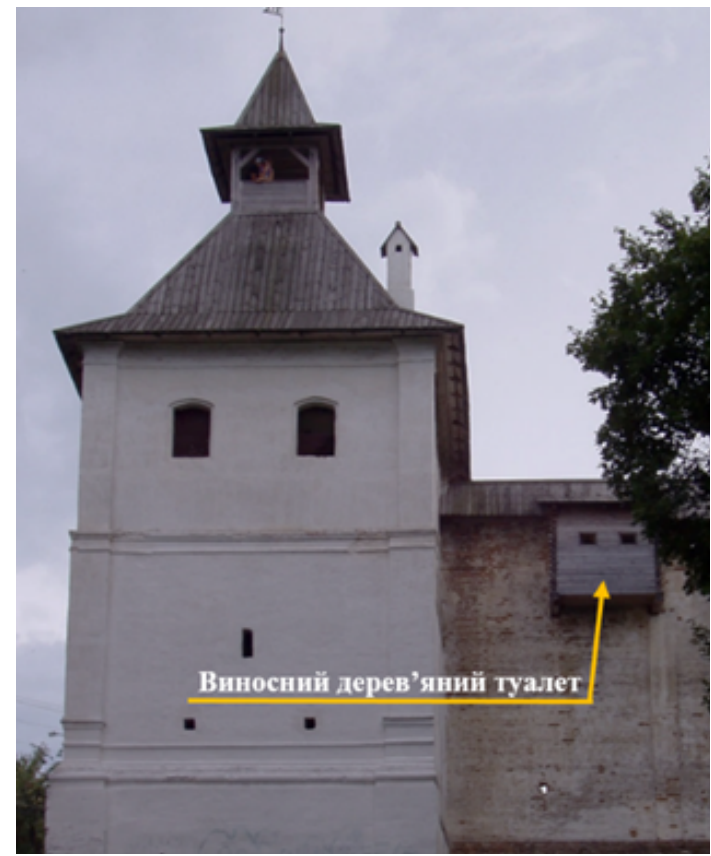

Iл. 10. Східна вежа Спасо-Преображенського монастиря у Новгороді-Сіверському після реставрації. Вигляд з боку поля. Вежа мала пічне опалення та виносний дерев'яний туалет в рівні бойового ходу монастирського муру. Фото 1998 p.

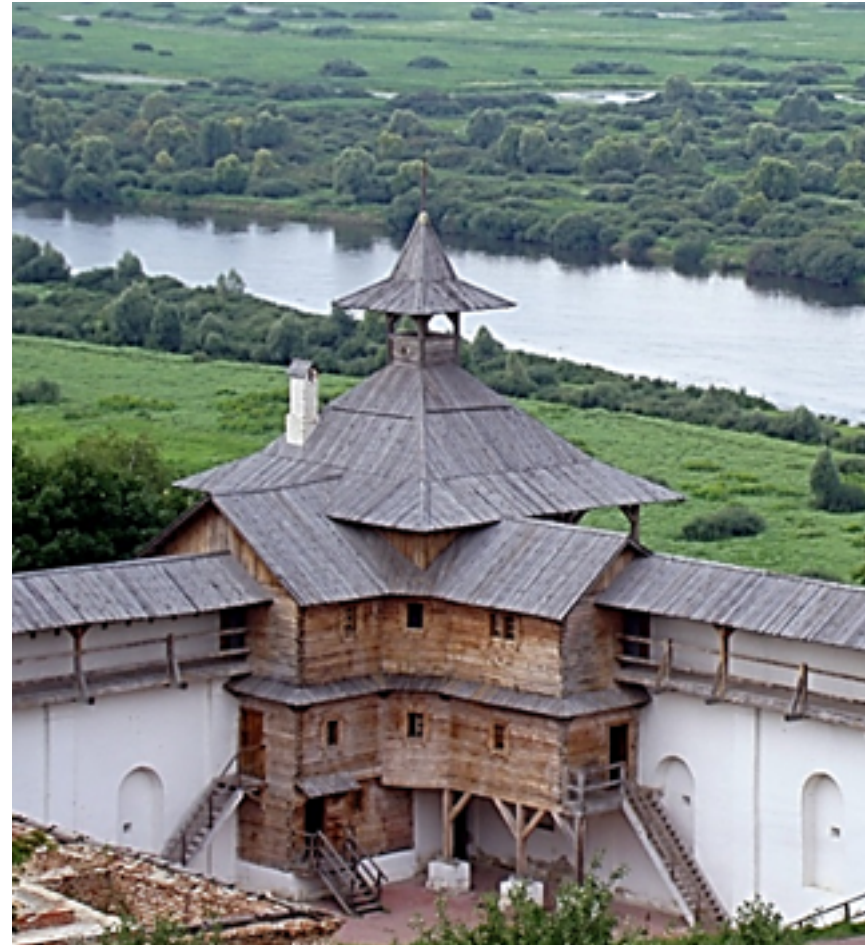

Iл. 9. Північна вежа Спасо-Преображенського монастиря у Новгороді-Сіверському після реставрації. 1998 р.

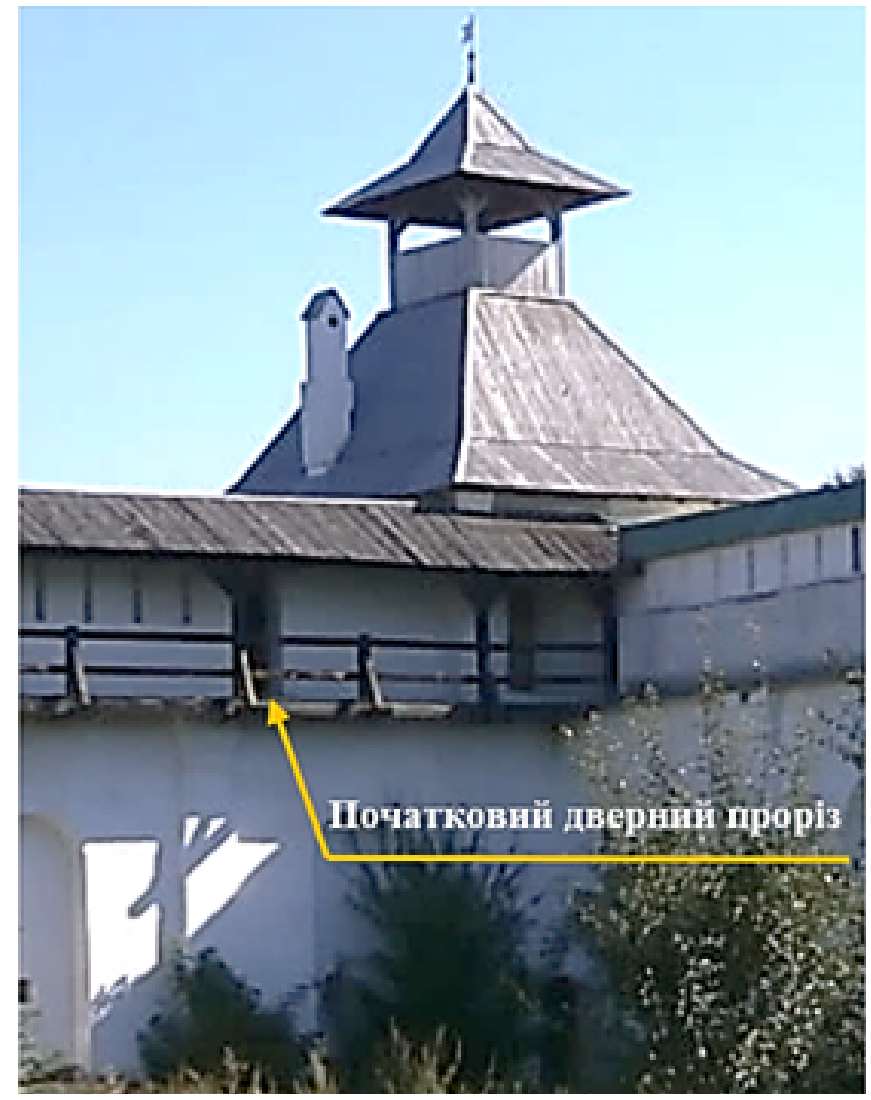

Iл. 11. Східна вежа Спасо-Преображенського монастиря у Новгороді-Сіверському після реставрації.

Вигляд з боку монастирського подвір'я.

Початковий дверний проріз, що зберігся це вхід до зовнішнього виносного туалету 


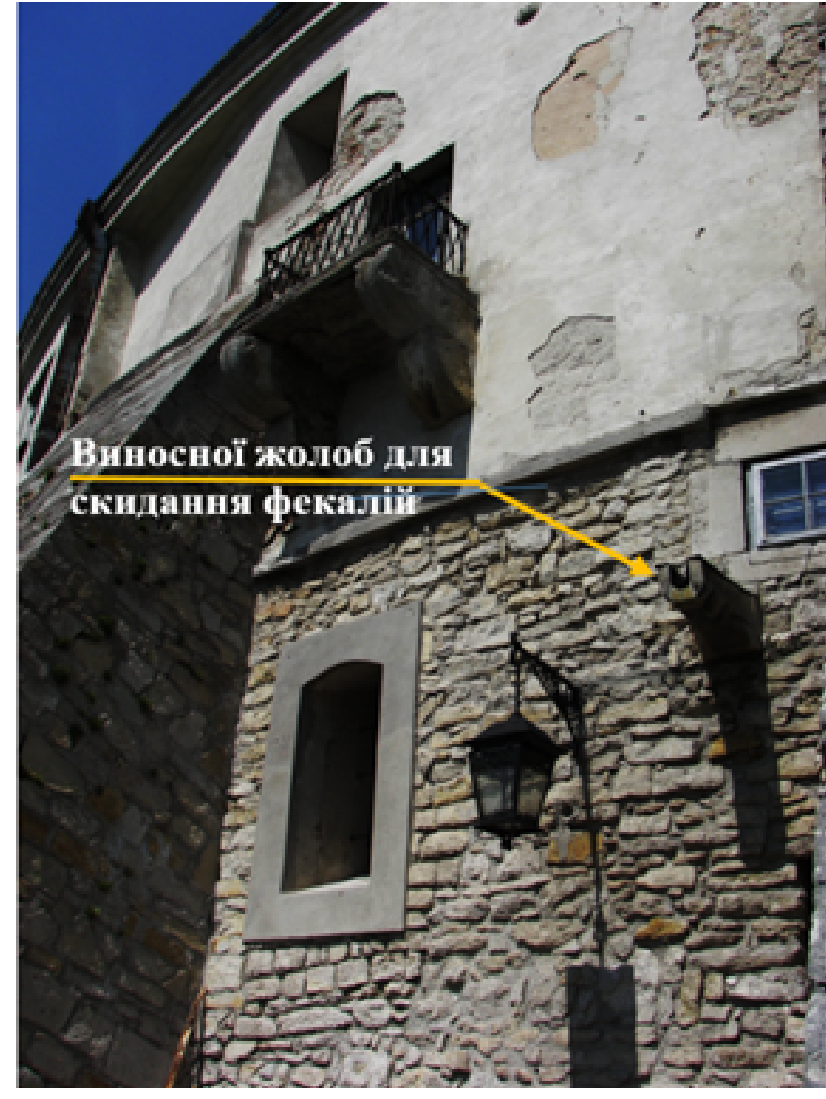

Iл. 12. Україна, замок XIII-XVIII ст. у містечку Олесько. Фрагмент зовнішнього фасаду з виносним жолобом для скидання фекалій з туалетної кімнати

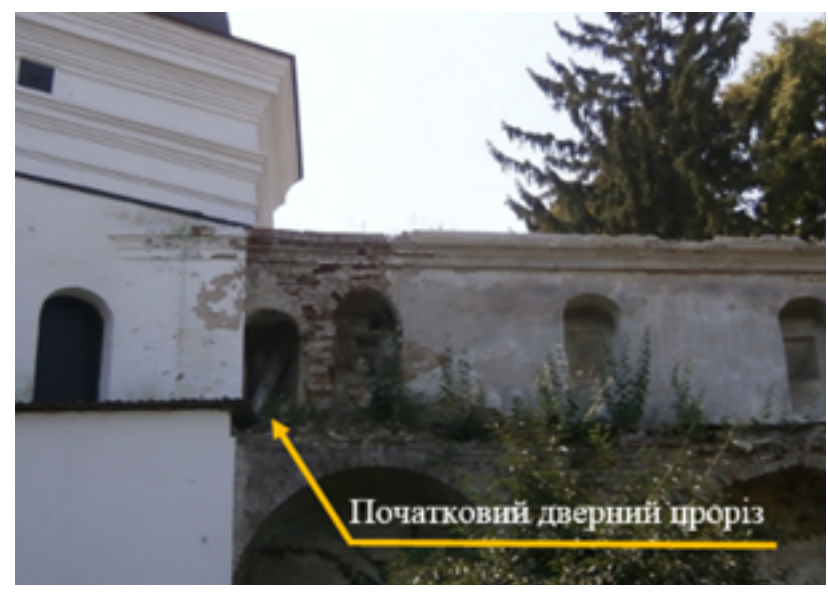

Іл. 14. Фрагмент ділянки стіни №1 біля Південної башти. Вигляд з боку монастирського подвір'я

Іл. 16. Фрагмент ділянки стіни № 1 біля башти Івана Кушника.

Вигляд з боку монастирського подвір'я

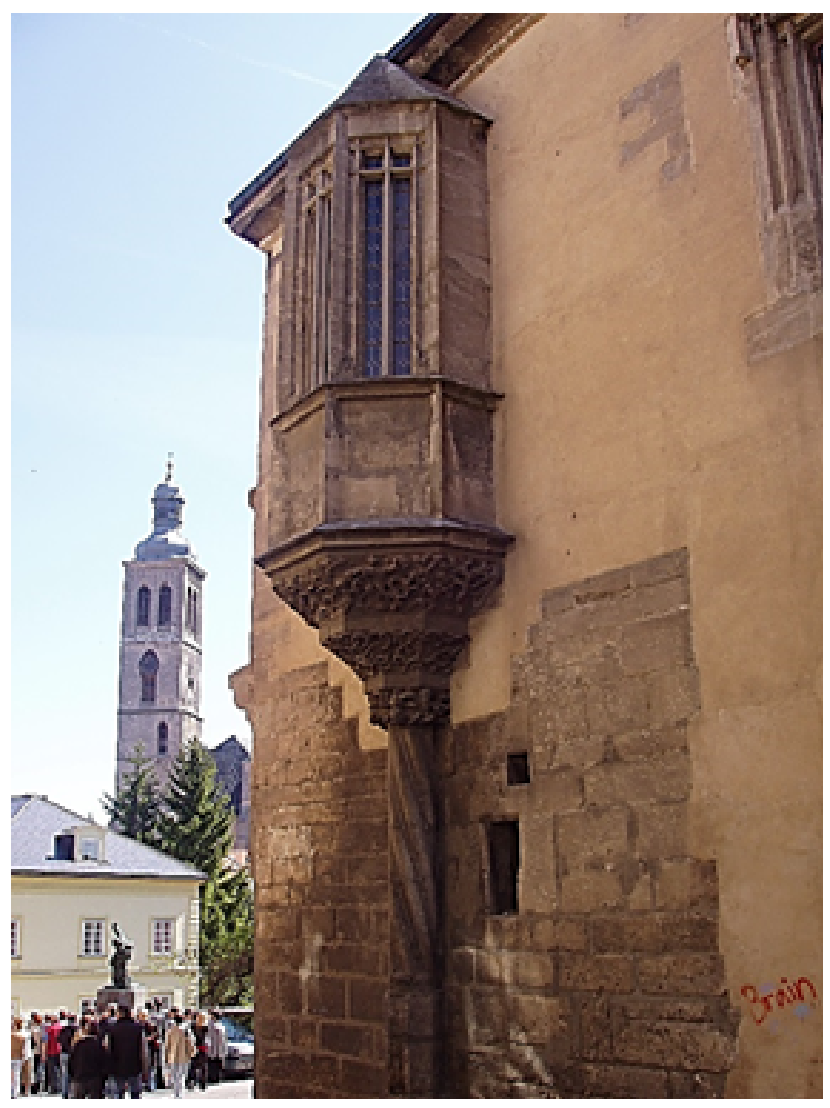

Iл. 13. Чехія, місто Крупна Гора. Будинок XIV ст. Виносний туалет на фасаді будинку з боку вулиці

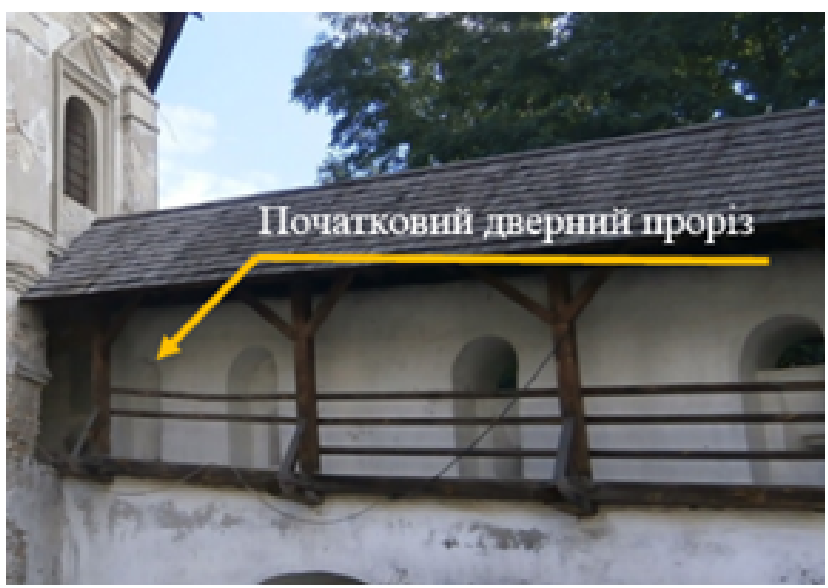

Іл. 15. Фрагмент ділянки стіни №14 біля Онуфріївської башти. Вигляд з боку монастирського подвір'я

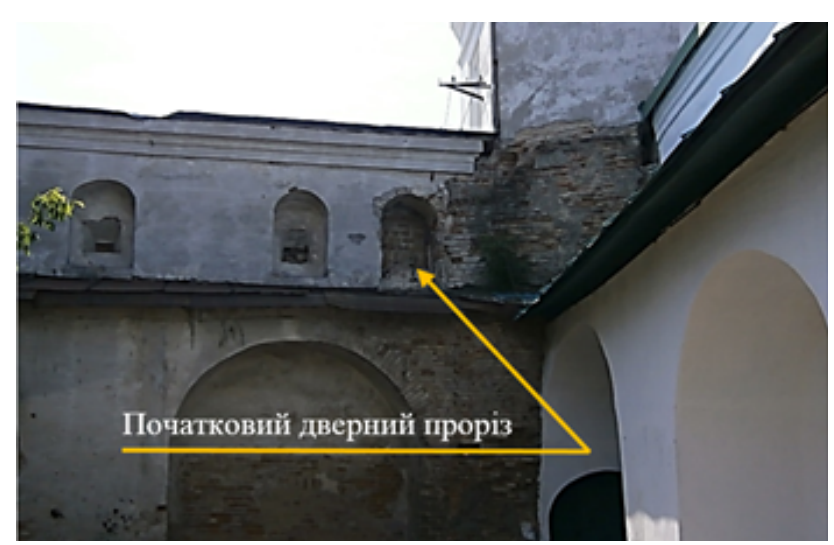




\section{РАННЬОМОДЕРНЕ мІсто}
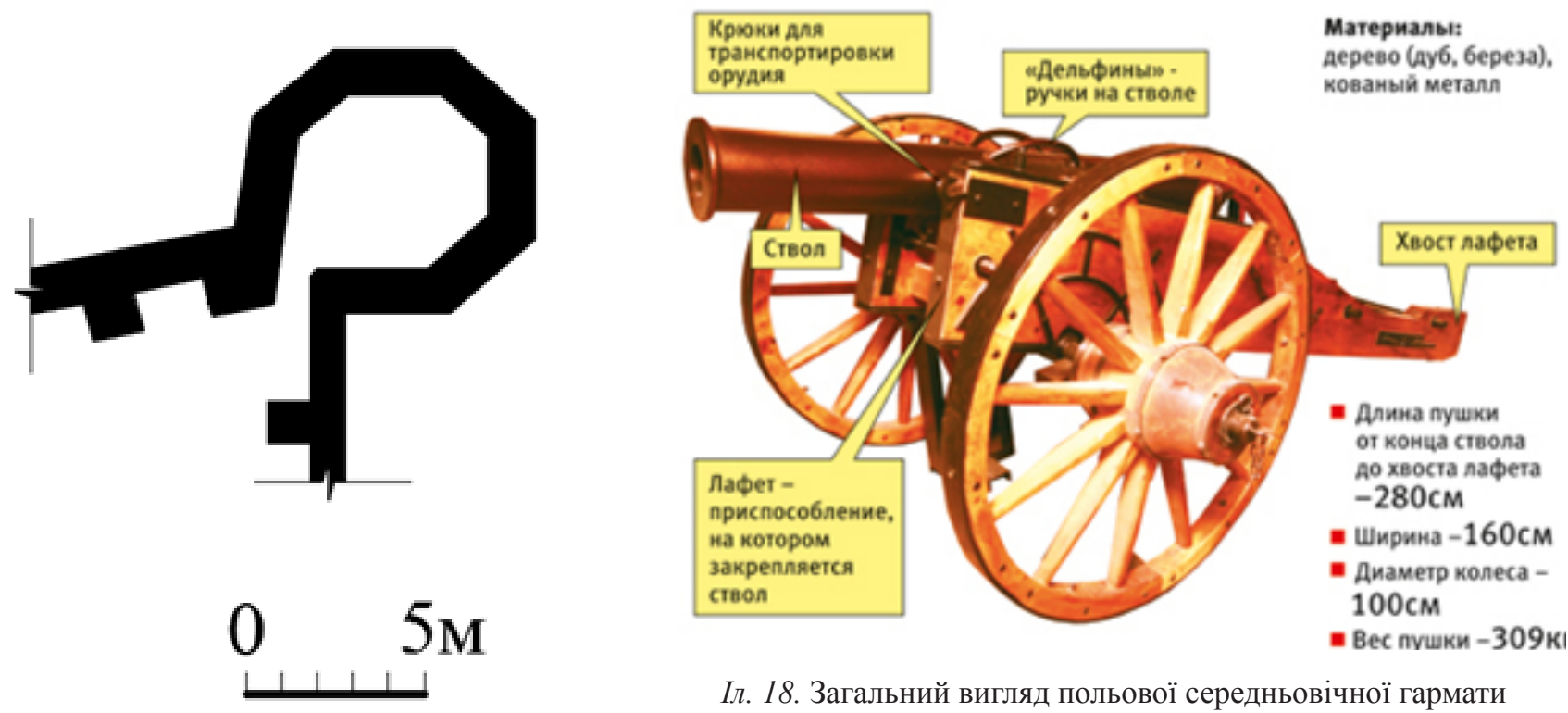

Іл. 18. Загальний вигляд польової середньовічної гармати

Iл. 17. Схематичний план першого ярусу башти Івана Кушника

Iл. 19. Шведський гармаш закладає в жерло гармати заряд.

Поруч знаходиться інший солдат, який в руках тримає банник. XVII ст.

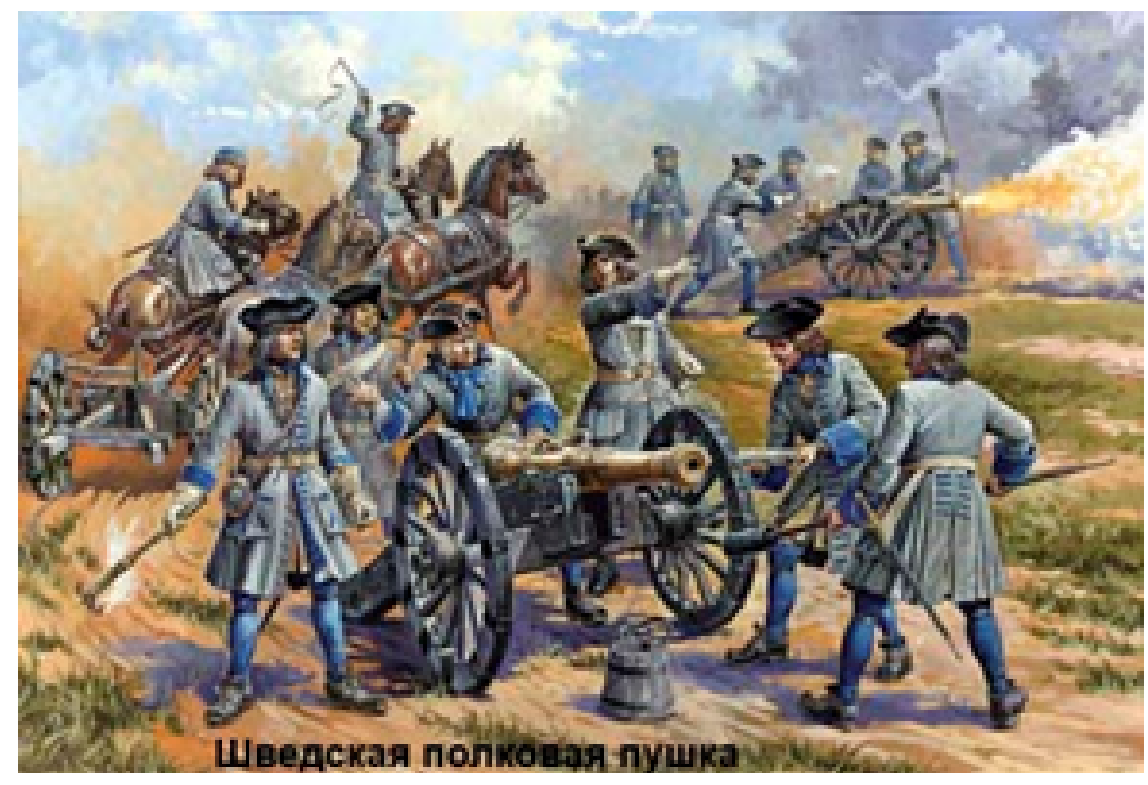

Iл. 20. Французький гармаш проштовхує заряд у ствол гармати. XVIII ст.

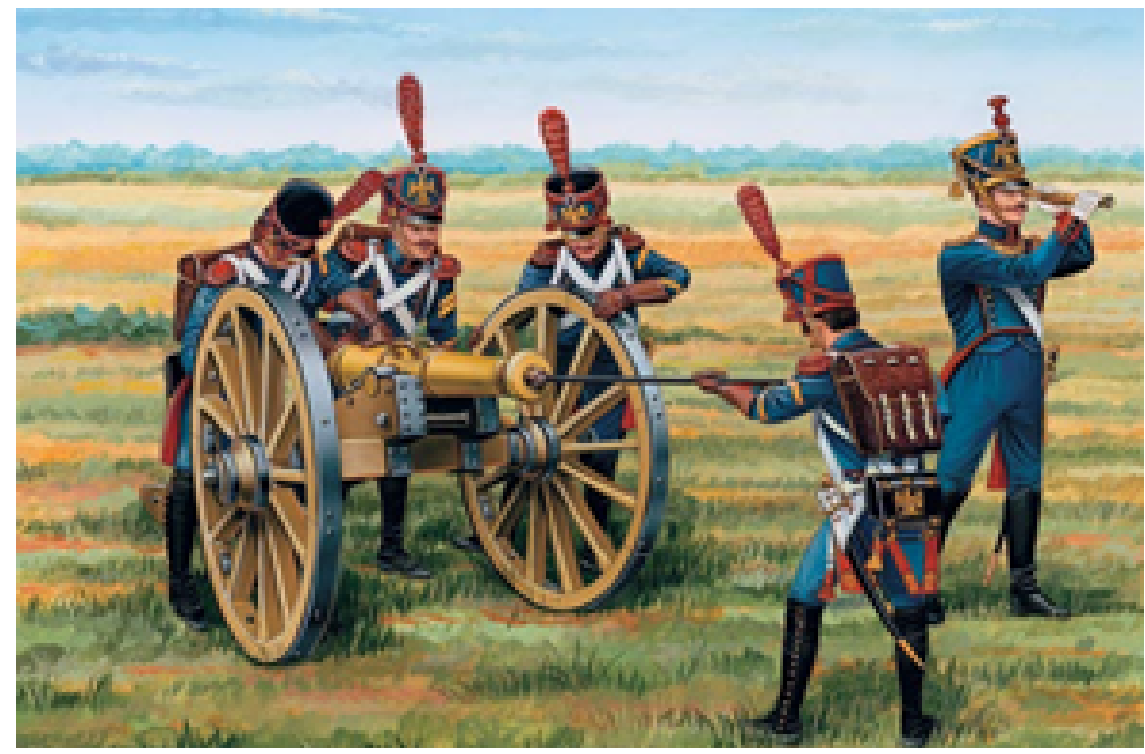


${ }^{7}$ Мальченко, О. (2017). Київський артилерійський арсенал у другій половині XVII ст. Київ: Академперіодика. пі, щуе не існувало, як і взагалі не існувало диференичіаиії гармат за родами військ. Одні й ті самі гармати могли передаватися за потреби з фортеці в польову армію (польову артилерію) або ж до піхотного корпусу, сформованого для певної облогової операциї (облогова артилерія) ${ }^{7}$.

У XVII ст., щоб зарядити будь яку гармату, потрібно у ствол 3 боку жерла закласти заряд (Іл. 19) і заштовхати його до кінця (до упору) за допомогою банника (Іл. 20). Таким чином, загальна довжина простору під час заряджання гармати буде дорівнювати довжині самої гармати (280 см) + довжина банника (200 см) + габарит людини ( $\geq 50$ см), який тримає банник + габарит людини ( $\geq 50$ cм), що відтягує гармату від амбразури за хвостовик лафету, що складає 580 см. Габарити приміщення першого ярусу вежі Івана Кушника 450 см х 450 см. 3 цього виходить, що гармати всередині башт Києво-Печерської лаври не встановлювалися. Звичайно, можна заперечити, що існували гармати й менших габаритів (Іл. 21). Але, маленькі гармати зазвичай використовувалися як сигнальні. Вогнепальна зброя кожного калібру має свій особливий звук пострілу - «голос». Сигнальні гармати не застосовувалися підчас бою для враження ворога. Їх «голос» мав відрізнятись на тлі загальної стрілянини для надання наказів війську.

Зображені на Іл. 22 гармати на металевих фортечних лафетах у місті Чернігові, які принципово відрізняються від дерев'яних лафетів польових гармат своєю конструкцією та великими габаритами. Ці лафети були привезені з Києва наприкінці ХІХ ст. на вшанування пам’яті про стародавню фортецю, що колись існувала на цьому місці.

Насправді, в інтер〉єрах башт Києво-Печерської лаври архітектурні натурні дослідження не виконувалися в обсязі, достатньому для наукової реконструкції їх початкового вигляду. Ці роботи ще належить виконати. Тільки після їх завершення можна буде з'ясувати, яка зброя застосовувалася для захисту монастирських укріплень. Проте, вже зараз можна сказати, що для ведення бою 3 мурів Києво-Печерського монастиря, збудованих у 1698-1701 pр., використовувалася саме вогнепальна зброя. Про це свідчать форма бійниць та вентиляційні отвори над ними. Один з таких вентиляційних отворів зберігся на східній грані башти Івана Кушника в рівні другого ярусу (Іл. 23).

Ці отвори були призначені для виходу порохових газів, тобто густого диму - продуктів горіння димного пороху: селітри, сірки, перетертих волокон конопель та льону, а також вугільного пилу. Площі бійниць було недостатньо для обміну повітря в приміщенні під час стрілянини, тому у верхній частині стіни приміщення робили прорізи для виходу диму. Таку систему вентиляції можна простежити на всіх фортифікаційних спорудах Києва від оборонних стін Києво-Печерської лаври до укріплень Київської фортеці (Іл. 24), побудованої в 1856 році. Бездимний порох з'явився в Російській імперії тільки на початку ХХ ст.

Така сама система вентиляції існувала і на східній вежі Спасо-Преображенського монастиря у Новгороді-Сіверському (Іл. 10), де на першому іiі ярусі існують дві квадратні бійниці для рушниць, 


\section{РАнHЬOMOдерHe Micto}

Iл. 21. Гармата XVII ст. завдовжки $25 \mathrm{~cm}$.

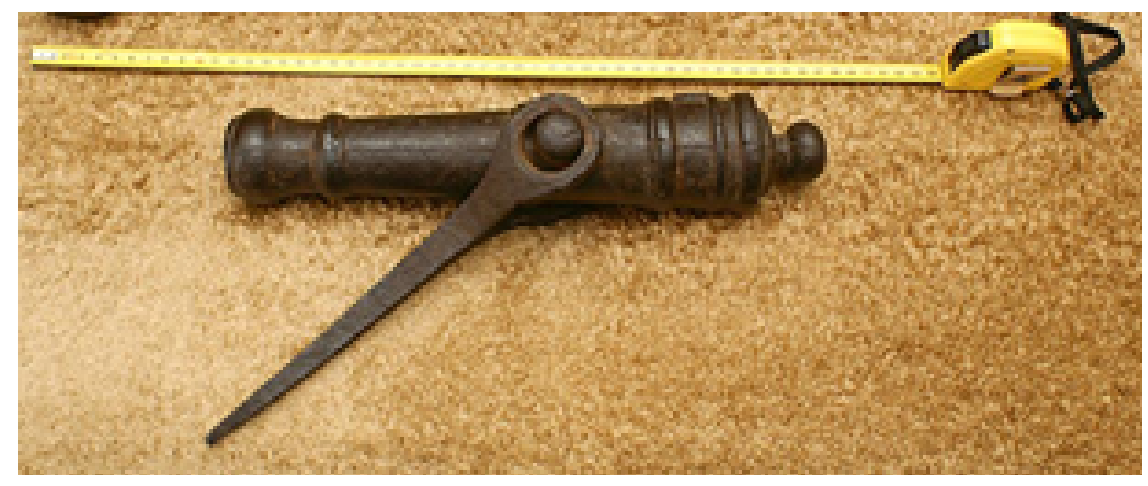

Iл. 22. Гармати XVII-XVIII ст. для захисту фортець на металевих лафетах. Чернігів

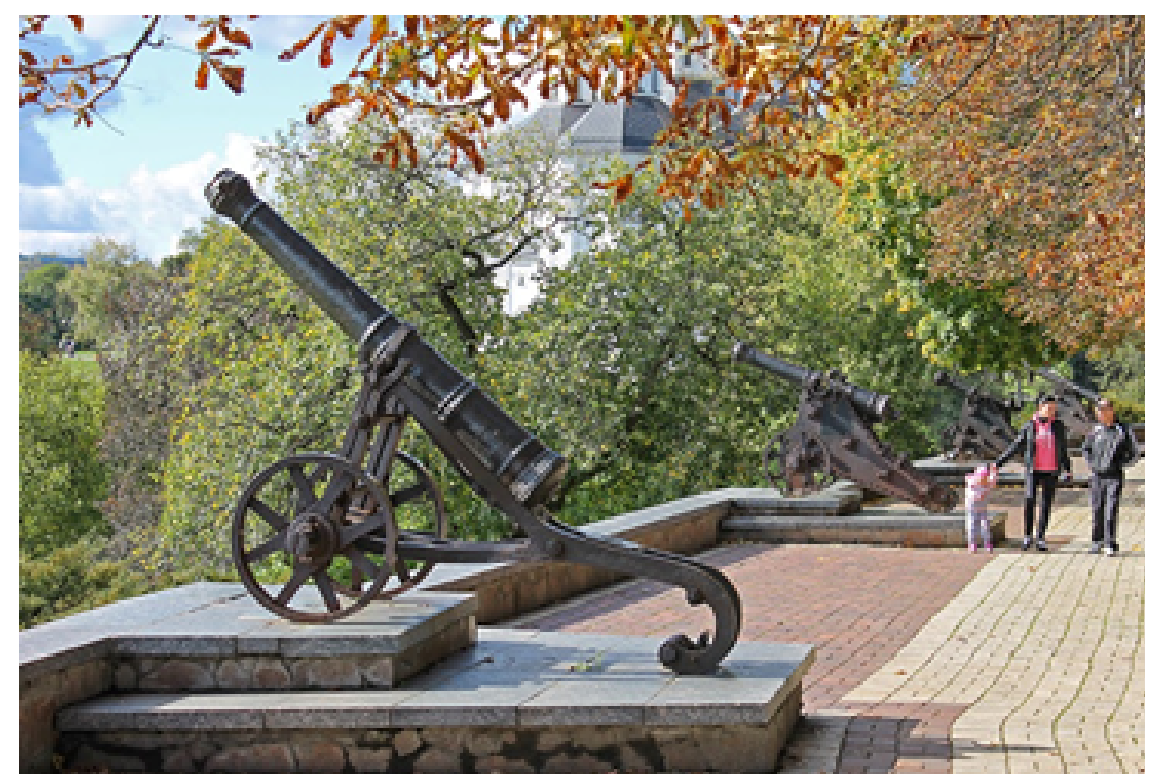

Iл. 23. Фрагмент східної грані фасаду башти Івана Кушника. Над прямокутною бійницею круглий вентиляційний отвір

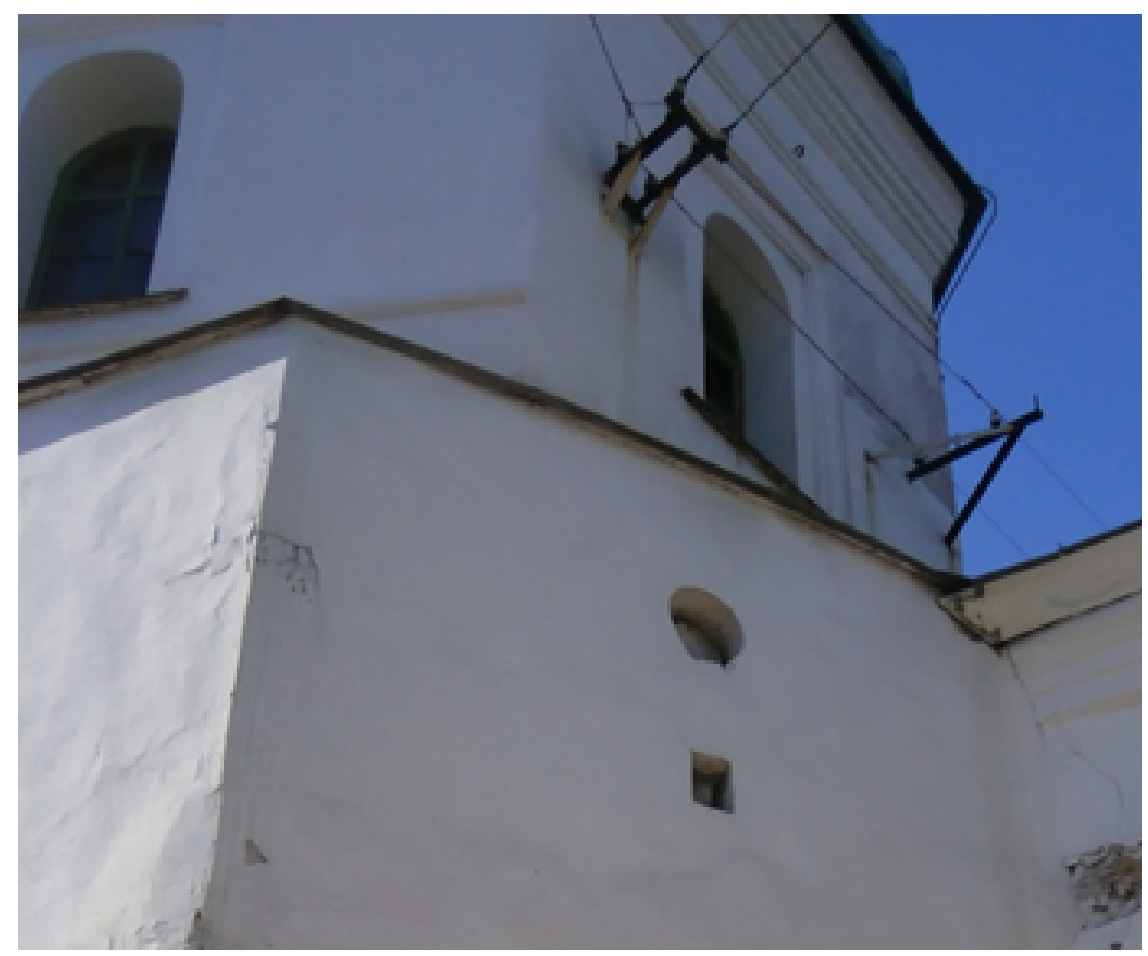


Іл. 24. Київська фортеця. Башта № 5, 1833-1846 pp. (Oxор. № 867/23).

Київ, вул. Печерський спуск, 16. Горизонтальні прорізи на фасаді першого та другого ярусів призначені для виходу порохових газів

Іл. 25. Бійниця для стрільби 3 рушниці на ділянці №12 монастирських мурів. Вигляд з боку бойової галереї

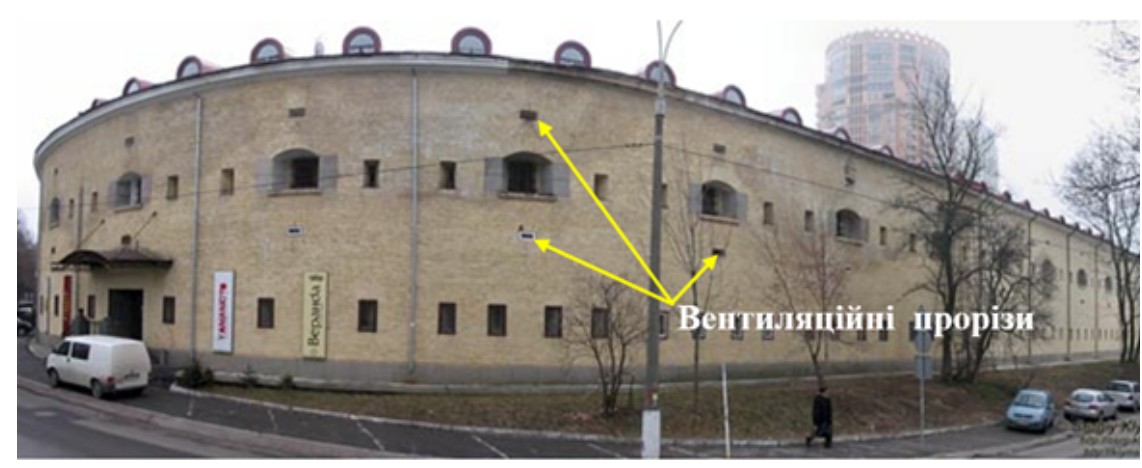

а над ними - витягнутий по вертикалі прямокутний проріз для виходу порохових газів. Під час архітектурних натурних досліджень було доведено, що ці три прорізи муровані одночасно. Це ще раз доводить, що для вогнепальної стрільби, яка велася з закритих приміщень, наявність вентиляції є обов'язковою умовою.

У ті часи вогнепальна стрілецька зброя була ще досить важка. Тому нижню частину бійниці використовували як упор. Щоб збільшити сектор обстрілу бійниця проходила не скрізь всю товщину муру, а знаходилася в глибині ніши з боку поля (Іл. 25). Нижня позначка бійниці зобов'язувала стрільця вести вогонь у положенні «з коліна», щоб постріл був більш влучнішим.

31886 р. Київська фортеця, до складу якої входила і Києво-Печерська лавра, переведена к фортецям 3-го класу, а 25 квітня 1897 року, з втратою стратегічного значення для оборони пере-

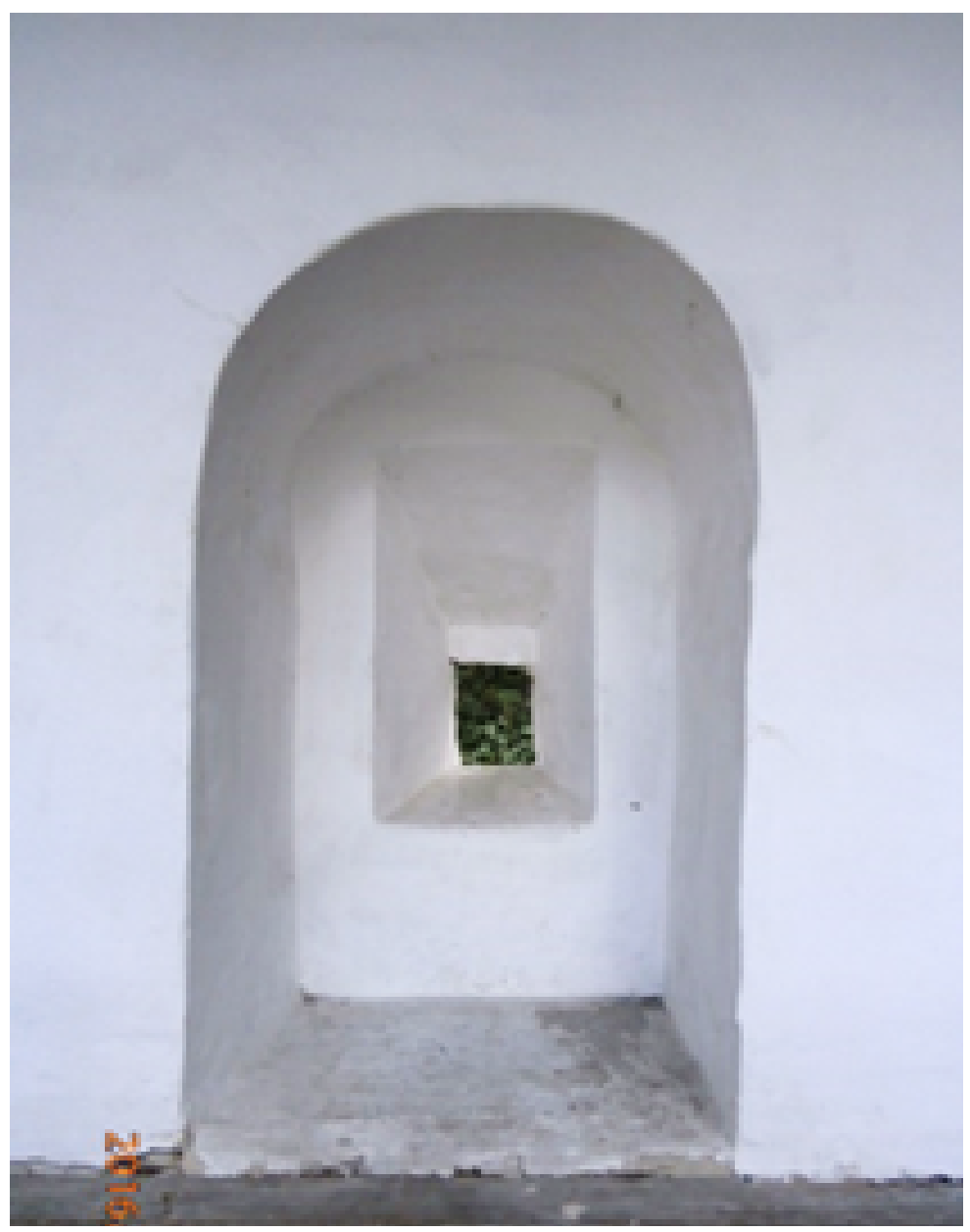


${ }^{8}$ Крайня, О. О. (2017). Вплив мілітаризації суспільства на життя Церкви в Україні (аналіз документів з історії КиєвоПечерської лаври 2-ї половини XVII-XVIII ст.). Церква - наука - суспільство: питання взаємодії. Матеріали П'ятнадцятої Міжнародної наукової конференції (29 травня 3 червня 2016 р). Київ, С. 19.

9 Там само. творена в фортецю-склад. І ось, коли монастирські стіни втратили своє початкове функціональне призначення біля них з'являються прибудови про які вже було зазначено. Наявність прибудов унеможливлює визначити загальну кількість бійниць в оборонних мурах. Так само неможливо уявити, що біля кожної бійниці мав стояти чернець з рушницею. На той час у Києво-Печерській лаврі не було стільки ченців, а тим паче рушниць.

Цікаву інформацію 3 цього питання отримуємо 3 нових матеріалів наукових досліджень співробітників НКПІКЗ: «Московський иар і бояри, обговорюючи кошторис заходів для посилення Київського гарнізону «приговорили» бути в Києві 15 тисячам стрільиів і солдатів. Безумовно виникали складнощі в розмішені такої сили військ і розпочався пошук місиь для утворення солдатських слобод, бо квартирування по домівках місиевих мешканиів не сприяло швидкій мобілізації.» 15 тисяч «стрільців $і$ солдатів» це приблизно 50\% війська, яке мав шведський король, коли бився 3 московським військом під Полтавою.

Тобто, спорудження цегляних стін навколо монастиря відбувалося з урахуванням розміщення частини «стрільців $і$ солдатів» московського війська. Виходить, що на території монастиря у відсутності військових дій одночасно перебували ченці і військові. Це припущення підтверджує той факт, що як компенсацію за утиски, яких зазнав Печерський монастир через військово-адміністративні зміни архімандрит Інокентій Гізель отримав у 1681 р. від царя грамоту, що у разі військової небезпеки, можна було б сховатися ченцям Києво-Печерської лаври у Свинському Успенському монастирі коло Брянська і Чолнському Преображенському коло Трубчевська. ${ }^{9}$

Якщо твердження, що в баштах Івана Кушника, Годинниковій та Онуфріївської знаходилися караульні приміщення вірне, то виникає питання, де знаходилася основна частина Московського війська, яка квартирувала на території Києво-Печерської лаври i, відповідно, мала боронити ііі від нападу з зовні.

Справа в тім, що на час спорудження цегляних мурів вся територія монастирського подвір'я була щільно забудована і для потреб гарнізону місця не вистачало. Єдине правильне рішення при обставинах, що склалися це спорудження казематів і різних прибудов до оборонних мурів з боку монастирського подвір'я. Але де саме, на яких ділянках мурів знаходилися ці прибудови?

Аналізуючи зображення на світлинах Іл. 26,27 задаємося питанням про велику кількість та надмірні габарити вентиляційних прорізів над бійницями галереї другого ярусу монастирського муру. Насправді, на відкритій галереї ці вентиляційні отвори непотрібні. На дослідженій і відреставрованій ділянці муру №12 ї ніколи не було (Іл. 7,25). А наявність цих отворів на ділянках №2, 3, 4, 5 та 14 можна пояснити тільки їх подвійним призначенням (для вентиляції і освітлення). Тобто, з боку монастирського подвір'я, спершу тут існували прибудови, які не збереглися (Іл. 28).

Імовірно, що саме у цих прибудовах квартирували «стрілецькі полки М. Уварова та Л. Из 'єдинова» ${ }^{10}$. Ці споруди були двоповерховими, стояли впритул до мурів і мали з ними спільний дах. 


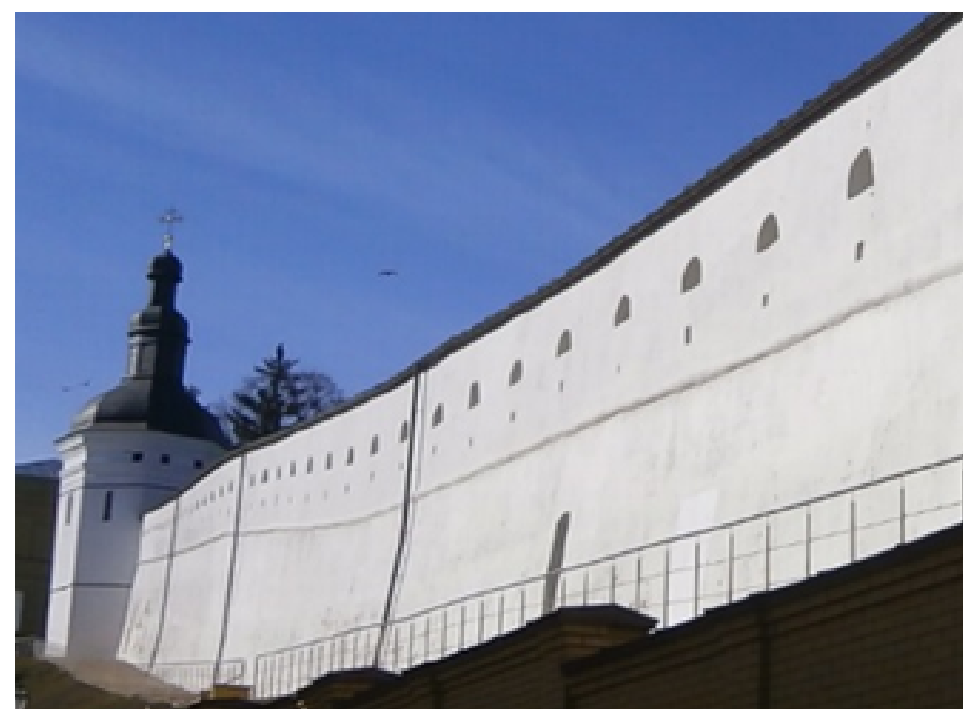

Iл. 26. Південна башта та ділянка монастирських мурів № 2 Києво-Печерської лаври. Загальний вигляд з південного сходу, де над бійницями влаштовані великі арочні прорізи

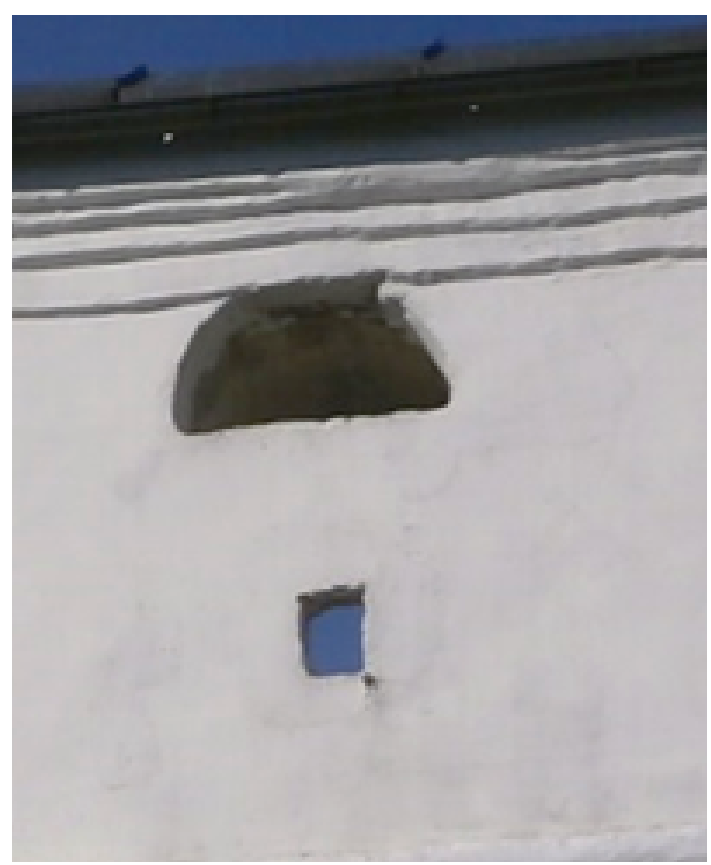

Іл. 27. Фрагмент ділянки монастирських мурів №2 Києво-Печерської лаври з бійницею та арочним прорізом

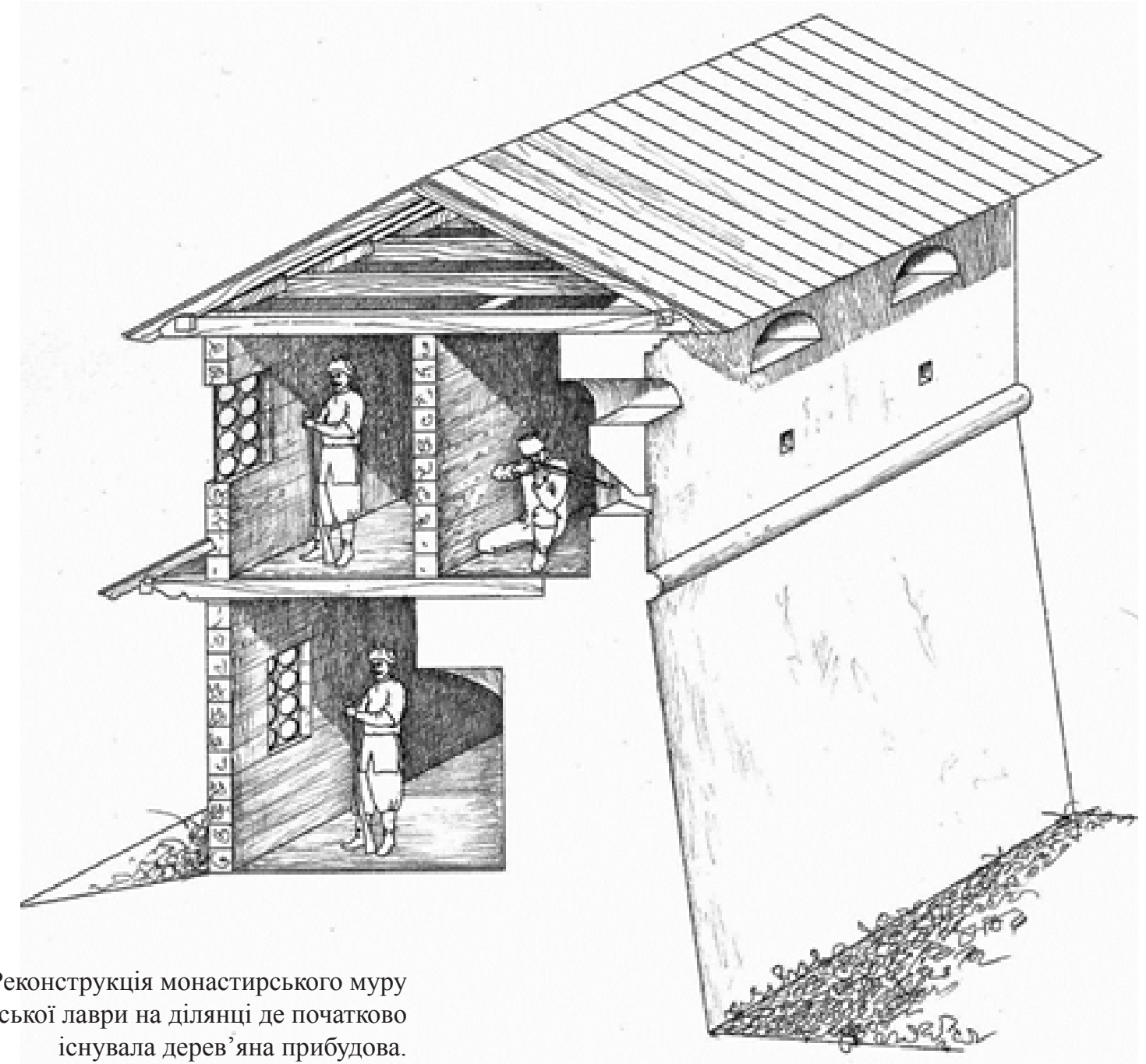

Києво-Печерської лаври на ділянці де початково снувала дерев’яна прибудова. Малюнок Лук'янченка В.I. 
${ }^{11}$ Петров, С. С. (2012). Оборонні споруди Києва X-XIX ст. у контексті історії міста i загального розвитку військово-фортифікаційної справи. Київ: Експрес-Поліграф, 232.

${ }^{12}$ Сіткарьова, О. В. (2005). Архітектурний ансамбль Києво-Печерської лаври та іï історичного оточення за доби гетьмана I. С. Мазепи. Київ: Довіра, 41.
Вони могли бути побудовані з цегли або з дерева, як у Новгороді-Сіверському (Іл. 10). Денне світло потрапляло у приміщення прибудов через віконні прорізи з боку монастирського подвір'я. Споруджена прибудова разом з монастирським муром в рівні бойової галереї утворювали темний коридор (каземат) значної довжини. Світла, яке мало б потрапляти крізь бійниці, було замало. Тому для освітлення коридору прорізи з завершенням у вигляді арки мурували на всю ширину ніші, де були влаштовані бійниці.

Як зазначалося на початку статті, іноді прибудови будувалися одночасно зі спорудженням оборонних стін та веж і були їх невід'ємною частиною. Визначення «прибудови» вони отримали тільки тому, що для їх будівництва використовували іншій будівельний матеріал або їхнє зведення відбувалося під час наступного будівельного сезону.

Проте, є багато прикладів, коли за браком коштів або у випадку зміни пріоритетів наступний будівельний сезон так ніколи і не розпочинався. Така участь спіткала т. з. Кутову башту ${ }^{11}$ Києво-Печерської лаври, де було закладено підмурки та зведено тільки цоколь. Іншої думки дотримується О. Сіткарьова: «...архівні матеріали не залишають жодних сумнівів щодо ї̈ існування. Зображення цієё вежі є плані 1744 р. та інших планах XVIII cm. Ï̈ було розібрано $1822 p^{1 »^{12}}$

Башта проіснувала до початку XIX ст. На той час іiі функціональне призначення було вже втрачено, і тому конструкцій башти демонтували.

Загальновідомо, що фортифікаційні споруди відрізняються від інших зразків будівельної діяльності людини своєю принциповою функціональністю. Ця принциповість підпорядковує собі все інше. В оборонній архітектурі немає нічого зайвого або випадкового. Тому, роздивляючись Іл. 29, де зображено дверний проріз першого ярусу Кутової башти, звертаємо увагу на прямокутні гнізда на його укосах (Іл. 30,31).

Подібних гнізд немає в укосах дверних прорізів першого поверху ані в вежі Кушника, ані в Годинниковій.

Гнізда в укосах дверних прорізів використовуються для дерев'яних внутрістінних засувів, які завжди знаходяться з боку напряму відкриття дверного полотна. Одне гніздо має глибину, яка більша за ширину дверного прорізу, інша $-15 \div 20$ см. Підчас відкривання дверей (1, Іл. 32), дерев'яний брус, який виконує функцію засуву (2, Іл. 32$)$, повністю ховається у глибокому гнізді. Коли необхідно закрити проріз, двері зачиняються, засув витягують 3 глибокого гнізда і вводять у менше гніздо з протилежного боку прорізу, а другий край засуву, приблизно 20 см, залишається у глибокому гнізді. Тобто, виходить, що відкрити двері буде неможливо, доки не буде зламано засув. Треба зазначити, що дерев'яний брус, який виконує функцію засуву закладають у стіну підчас іiі мурування, звідси походить і назва «внутрістінний засув».

Такі засуви використовують для запирання двері із середини приміщення у випадках, коли це необхідно зробити надійно i швидко, i, таким чином, забезпечити безпеку людям, які знахо- 
Iл. 29. Сучасний вигляд дверного прорізу з боку монастирського подвір'я до першого ярусу Кутової башти (не зберіглася)

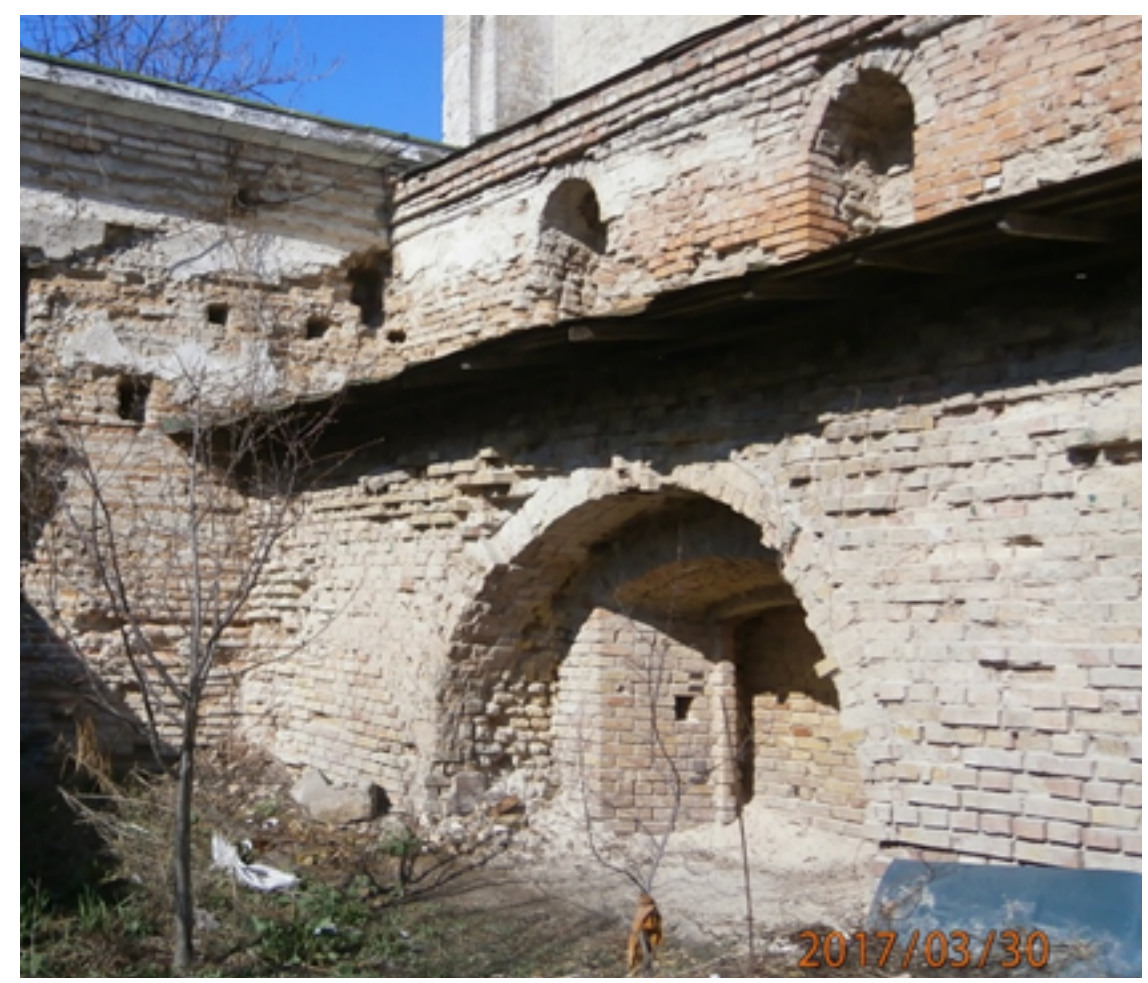

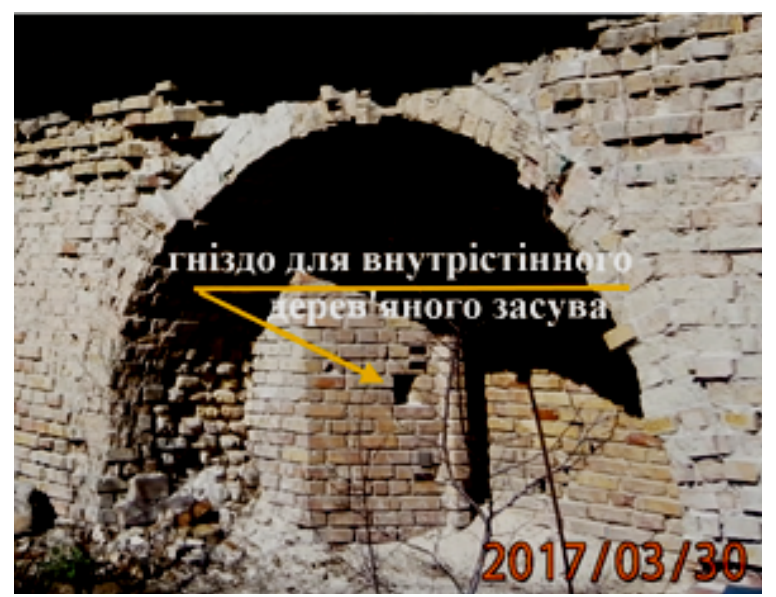

Іл. 30. Західний укіс дверного прорізу до першого ярусу Кутової башти

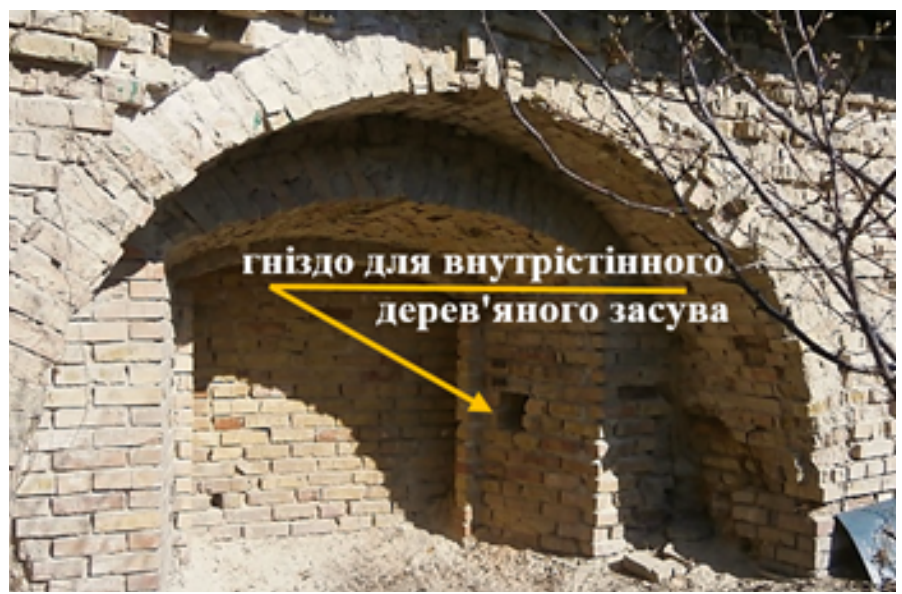

Iл. 31. Східний укіс дверного прорізу до першого ярусу Кутової башти

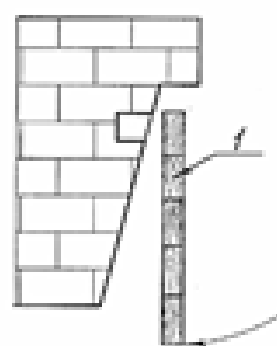

A

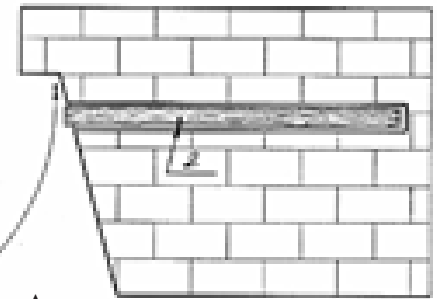



Б

Iл. 32. Положення внутрістінного засуву

підчас видкритого (А) та закритого (Б) дверного прорізу 
Iл. 33. Початковий вигляд башти Івана Кушника 3 південного боку. Реконструкція Лук'янченка В. I.
${ }^{13}$ Приміщення для утримання військових під тимчасовим арештом.

\footnotetext{
${ }^{14}$ Памятники градостроительства и архитектуры Украинской ССР. Т. 1. Киев, Киевская область. (1983). Київ: Будівельник, 60.
}

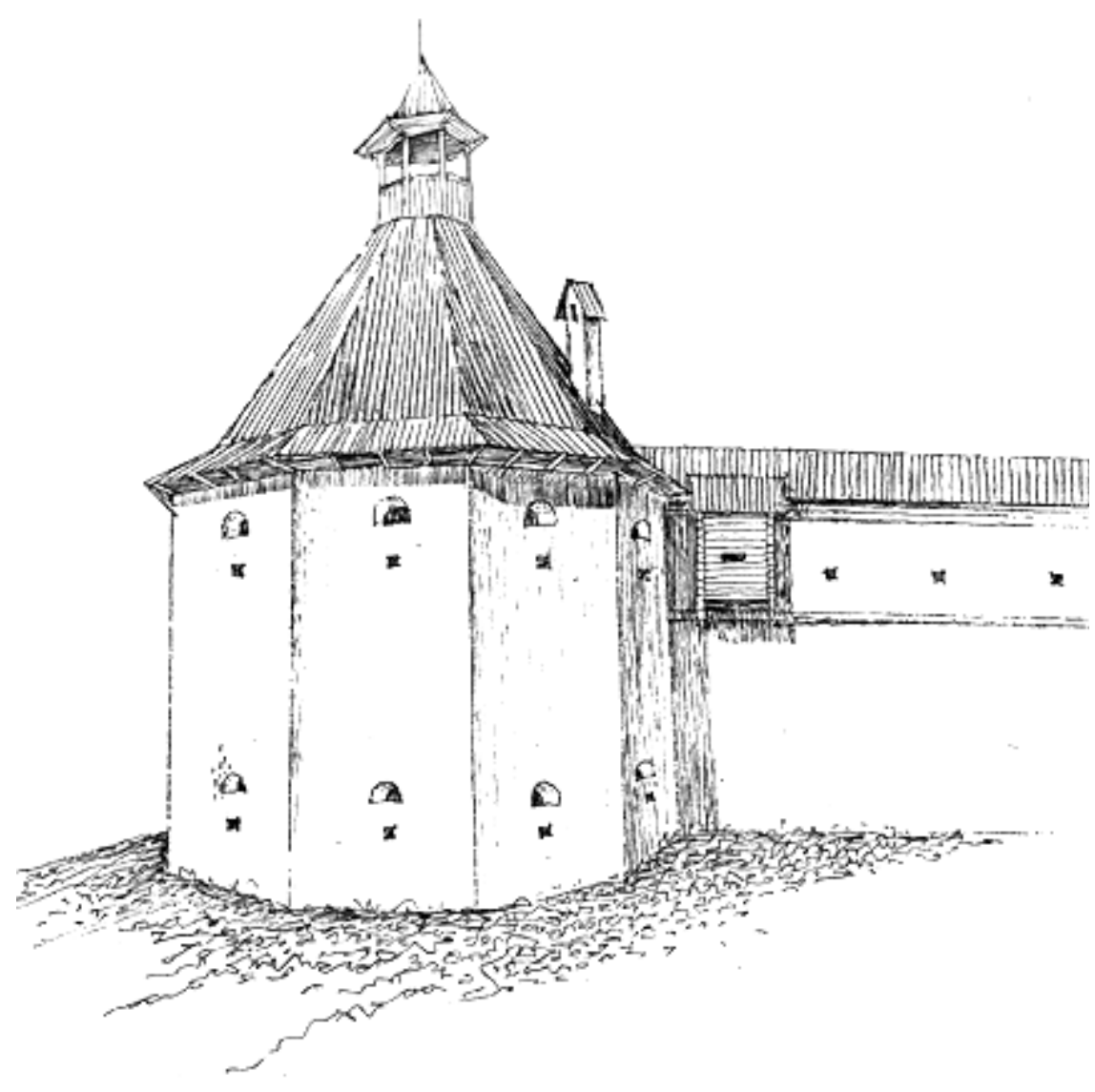

дяться в середині. Але, у нашому випадку, двері зачинялися ззовні. Так, що було за тими дверима у Кутовій вежі? Що там таке знаходилося, що потрібно було надійно зачинити? Припущення про те, що там знаходилася стайня можна відкинути. Сумнівно, щоб Кутова вежа була значно більша за площею ніж Кушника або Годинникова габарити яких не дозволяють використовувати їх під стайню. А от якщо припустити, що перший ярус Кутової вежі мав бути використаний як гауптвахта ${ }^{13}$, то все стає зрозуміло. Тому, що навіть група буйних але неозброєних арештантів не в змозі проломити такі двері. Гауптвахта - невід'ємна складова частина кожного гарнізону або тимчасового військового табору, як казарма, кухня або туалет.

Інакше склалася доля башти Івана Кушника. Вона була побудована як вартова вежа у 1698-1701 рр. і мала два яруси (Іл. 33). При реставрації 1718-1727 pр. надбудували третій ярус, і в такому вигляді вона проіснувала до нашого часу. ${ }^{14}$

За час свого існування істотних змін зазнала південна частина ділянки монастирських мурів №14, що знаходиться між корпусами №10 та №100 (Іл. 34,35). Північна частина ділянки стіни №14, яка була відреставрована на початковий період, значно вища за південну, яка знаходиться між корпусами №10 та №100, та за частину стіни, вбудовану у корпус №100. 3 боку монастирського подвір'я в стіні збереглися ніші від закладених віконних прорізів (Іл. 35), що належали прибудові, котра колись була на цьому місці.

Який вигляд мала ця прибудова на сьогодні визначити важко. Відомо, що до їі спорудження у верхній частині муру існували зубці (Іл. 36). Вони збереглися до теперішнього часу, тільки бійниці 
Iл. 34. Загальний вигляд монастирських мурів на ділянці №14, 14а з боку поля

Іл. 35. Загальний вигляд монастирських мурів на ділянці №14a 3 боку монастирського подвір'я

Iл. 36. Загальний вигляд Верхньої Лаври зі східного боку. Фрагмент світлини другої половини XIX ст. (до 1883 року)
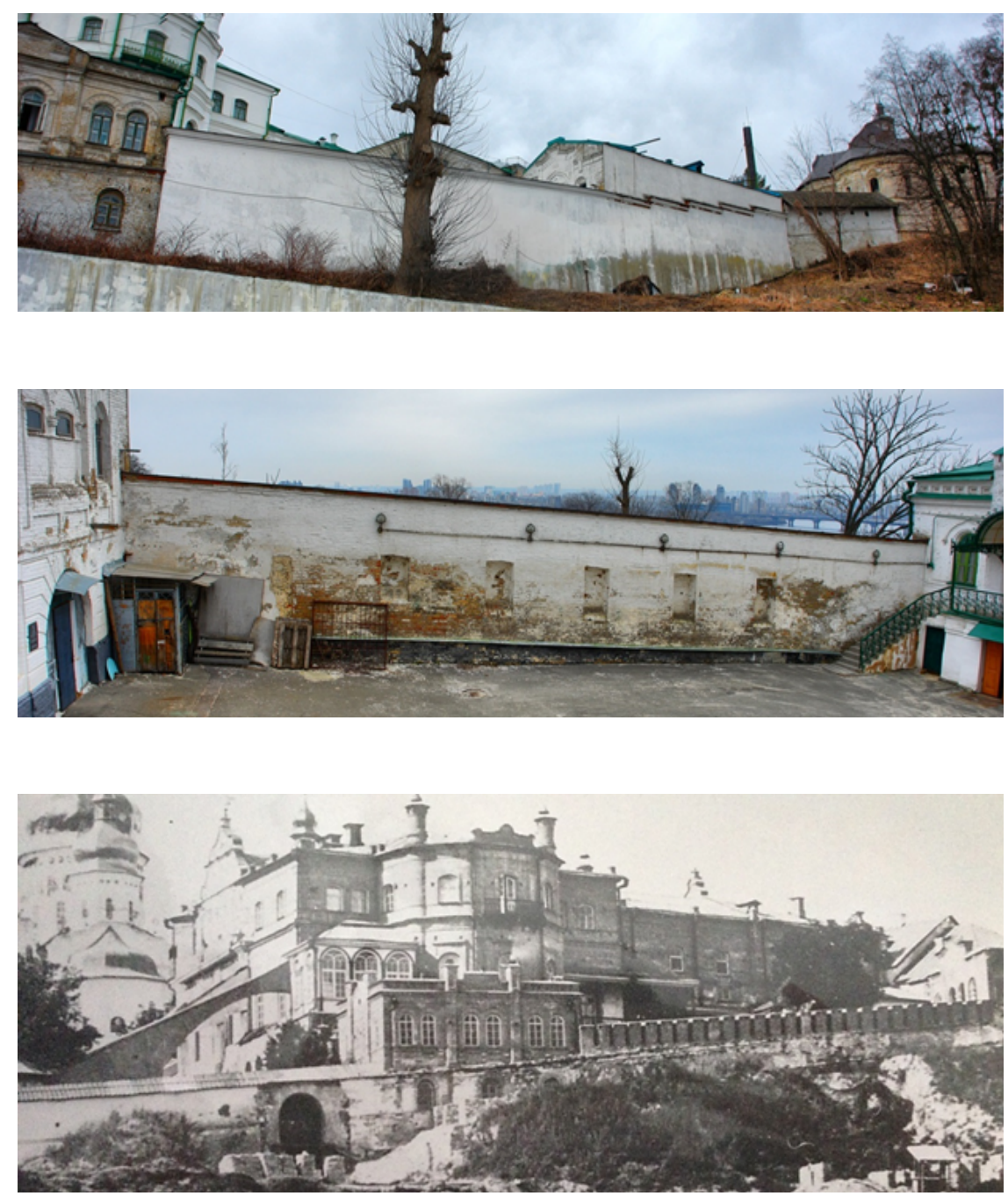

між ними заклали цеглою. Можливо, це сталося при споруджені прибудови, мова про яку була вище. Ця південна частина ділянки монастирських мурів №14 має значно меншу товщину стіни порівняно з іншими оборонними мурами Верхньої Лаври. Вона дорівнює всього 80 см і складена 3 іншої цегли, ніж іiї північна частина.

Можливо, оборонні мури, які попередньо існували, були демонтовані, і на цьому місті споруджені нові, які майже на два метри були меншої товщини. Таким чином, було заощаджено площу монастирського подвір'я.

Проте, на цій ділянці до другої половини XIX ст. взагалі могло не бути цегляного муру. Так, роботи зі зведення монастирських укріплень мали сезонний характер і тривали чотири роки (1698$1701 \mathrm{pp})^{15}$. Тривалість будівельного сезону у ті часи визначався температурою повітря, коли водний вапняний розчин не міг вкритися кригою (травень - жовтень). Роботи виконувалися саме настільки, наскільки вистачало коштів. Ми вже згадували про незавершене будівництво Кутової башти Києво-Печерської лаври, яка мала постати на північно-західному розі оборонних мурів (між ділянками №8 та №9 по Іл. 3) впритул до стін із зовнішнього боку. Ця башта мала стояти, так би мовити, за межами оборонного кола. Її відсутність не становила істотної загрози для безпеки монас- 
Іл. 37. Фрагмент монастирських мурів на ділянці №12 з боку монастирського подвір'я

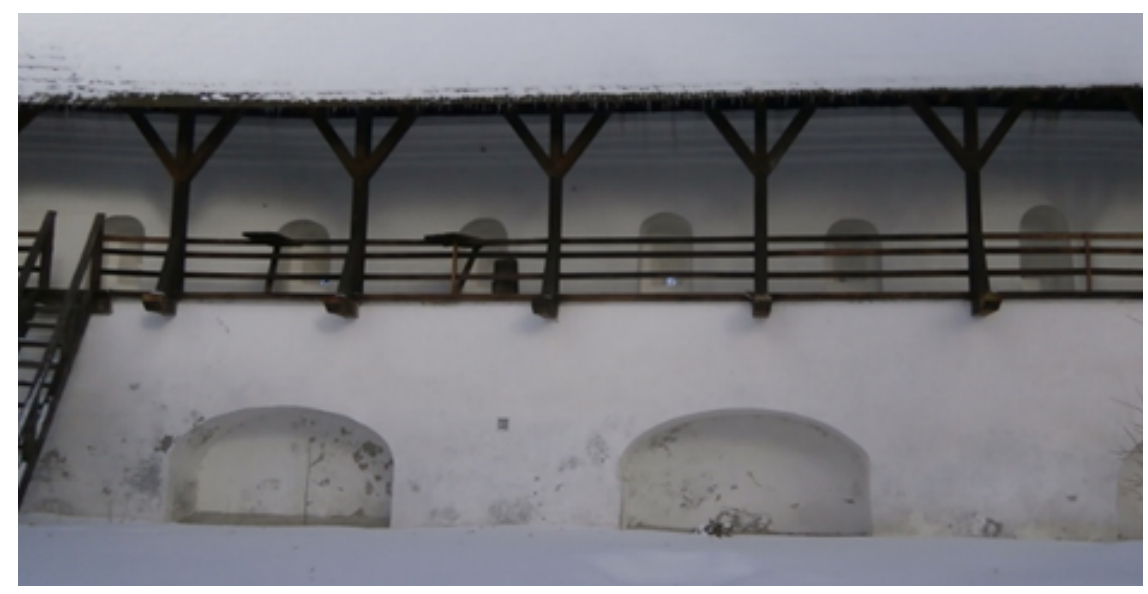

\section{Iл. 38. Фрагмент монастирських мурів на ділянці №6 з боку монастирського подвір'я}

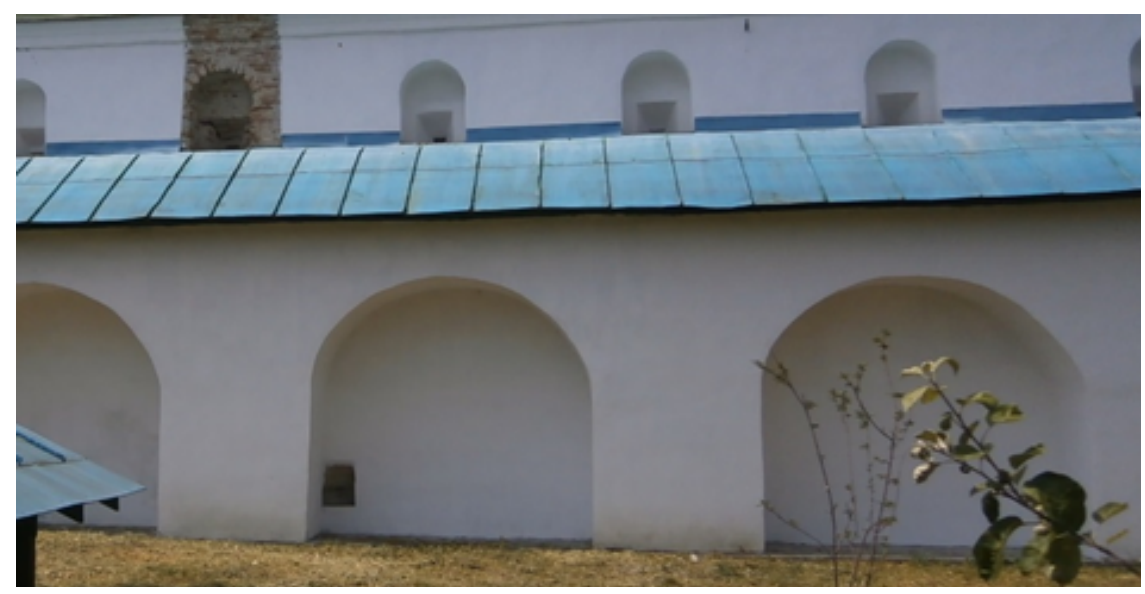

16 Замок князів Острозьких у м. Старокостянтинів. 3 боку міста стіни замку були 3 каменю, з боку річок земляні вали з городнями. тиря. А от недобудовану ділянку стіни, а, тим паче, розрив у оборонному колі лишати було неможна. У таких випадках використовували більш дешевий будівельний матеріал ${ }^{16}$. Аби замкнути коло оборонних укріплень, могли використати дерево-земляну стіну, яку ззовні вкривали вапняним тиньком. Таким чином, виходило, що візуально відрізнити потиньковану дерево-земляну стіну від потинькованої цегляної стіни було неможливо. У такому стані південна частина ділянки монастирських мурів №14а проіснувала до середини XIX ст., коли дерево-земляну стіну замінили на цегляну. Але це - лише припущення.

При візуальному обстеженні оборонних мурів, 3 боку монастирського подвір'я, кидається в очі принципова відмінність арочних ніш в першому їх ярусі на різних ділянках (Іл. 37,38,39).

На ділянці №12 (Іл. 37) простінок між нішами дорівнює габаритам самої ніші, а на ділянці №6 (Іл. 38) простінок удвічі менший за ширину самої ніші. На ділянці №6 арочні перемички звичайні напівциркульні, а на ділянці №12 вони трицентрові, або лучкові.

Цікаву особливість мають перемички на ділянці №2. На відміну від інших, вони в рівні п'яток мають невеличкі полиці для встановлення кружал (Іл. 39,40).

Наявність такого різного підходу до виконання будівельних робіт підтверджує той факт, що роботи по спорудженню монастирських укріплень мали сезонний характер. Щоразу працювали різні будівельні артілі, які намагалися виконати цю роботу краще за своїх попередників. До речі, при використанні полиць у простін- 


\section{Iл. 39. Фрагмент монастирських мурів на ділянці №2 з боку монастирського подвір'я}

Іл. 40. Фрагмент простінку 3 поличками для встановлення кружал на ділянці монастирських мурів №2
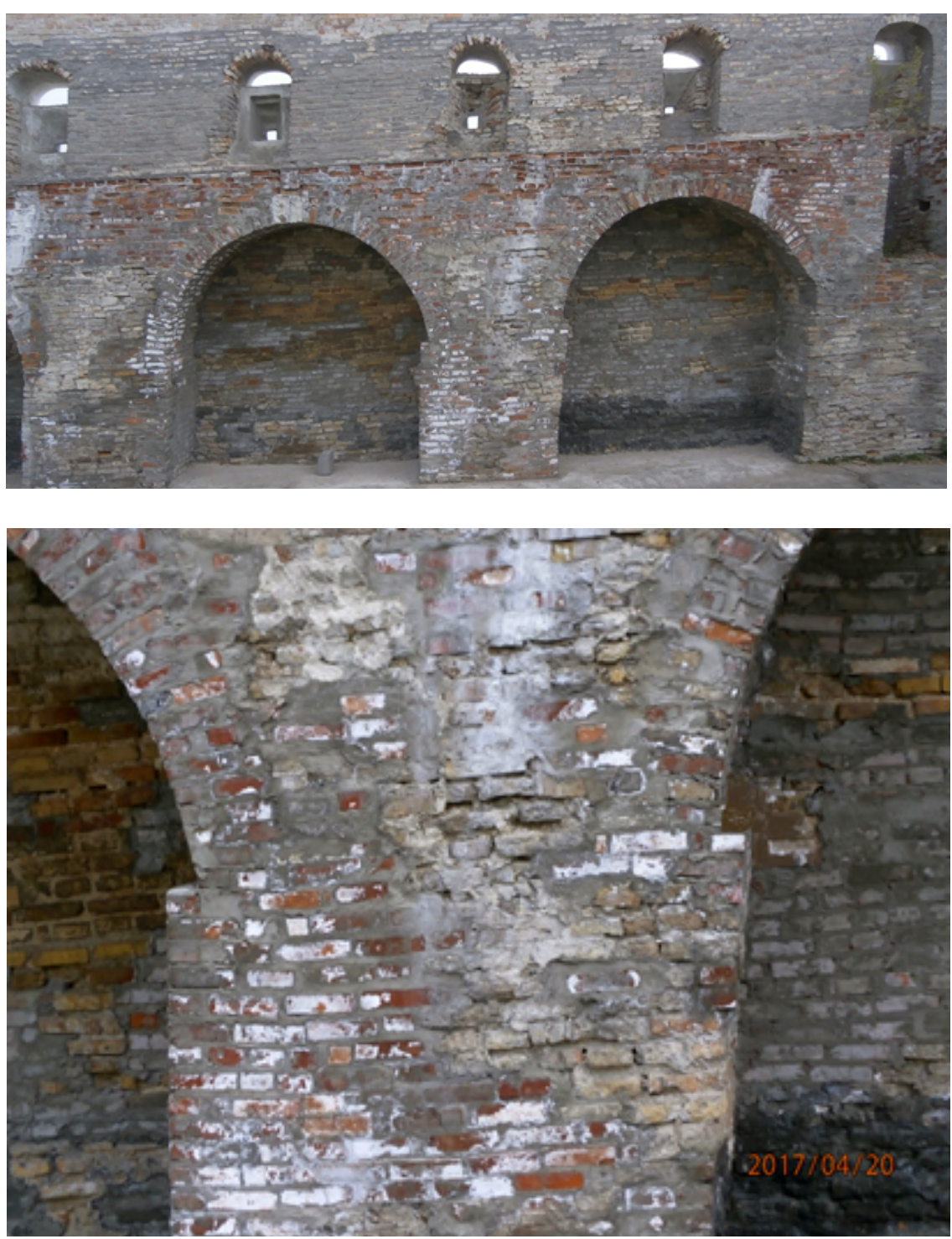

ках для встановлення кружал заощаджувалась значна кількість деревини на встановлення будівельних риштувань (Іл. 41,42).

Монастирські мури Києво-Печерської лаври тримають в собі ще дуже багато невідомої і цікавої інформації.

По-перше: аби підтвердити чи спростувати припущення про існування туалетів в рівні бойового ходу, необхідно виконати архітектурні натурні дослідження: зондажі у монастирських стінах 3 боку поля, в місцях під порогами передбачуваних дверних прорізів. Зондажами з'ясувати наявність гнізд від дерев'яних конструкцій виносних туалетів біля вежі Івана Кушника, Годинникової та Онуфріївської. Необхідно буде виконати комплекс архітектурних натурних досліджень в інтер'єрах для пошуку димохідних каналів від печей або камінів, габаритів та конфігурації початкових бійниць, рівня та конструкції перекриття. Та з'ясувати яким чином здійснювалося сполучення між ярусами веж.

По-друге: необхідно виконати археологічні дослідження біля ділянок монастирських мурів №2-5,14 з метою пошуку передбачуваних підмурків початкових прибудов. 


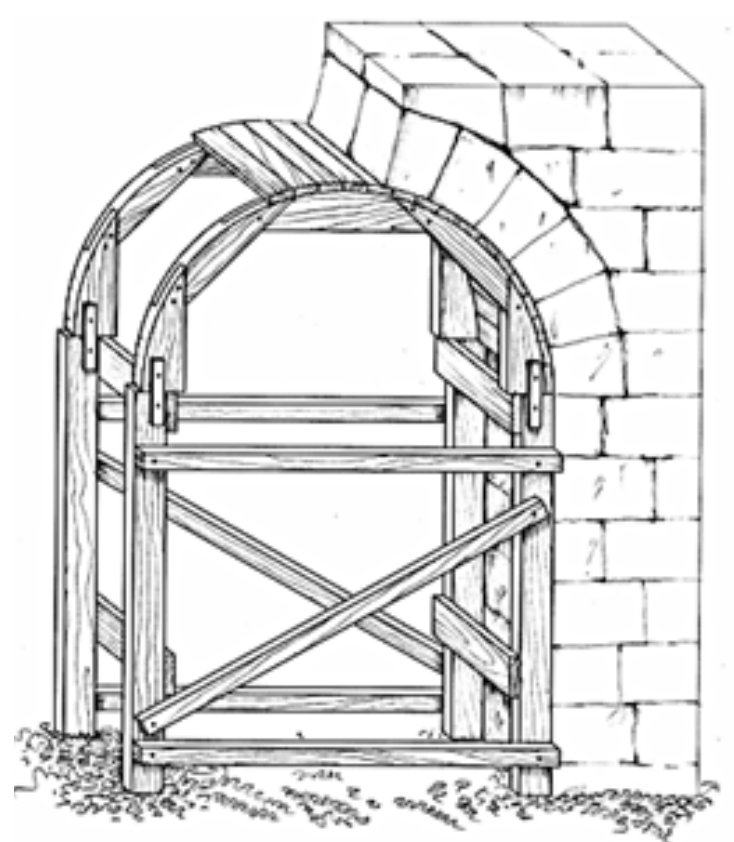

Iл. 41. Звичайна конструкція кружал для мурування арочних перемичок

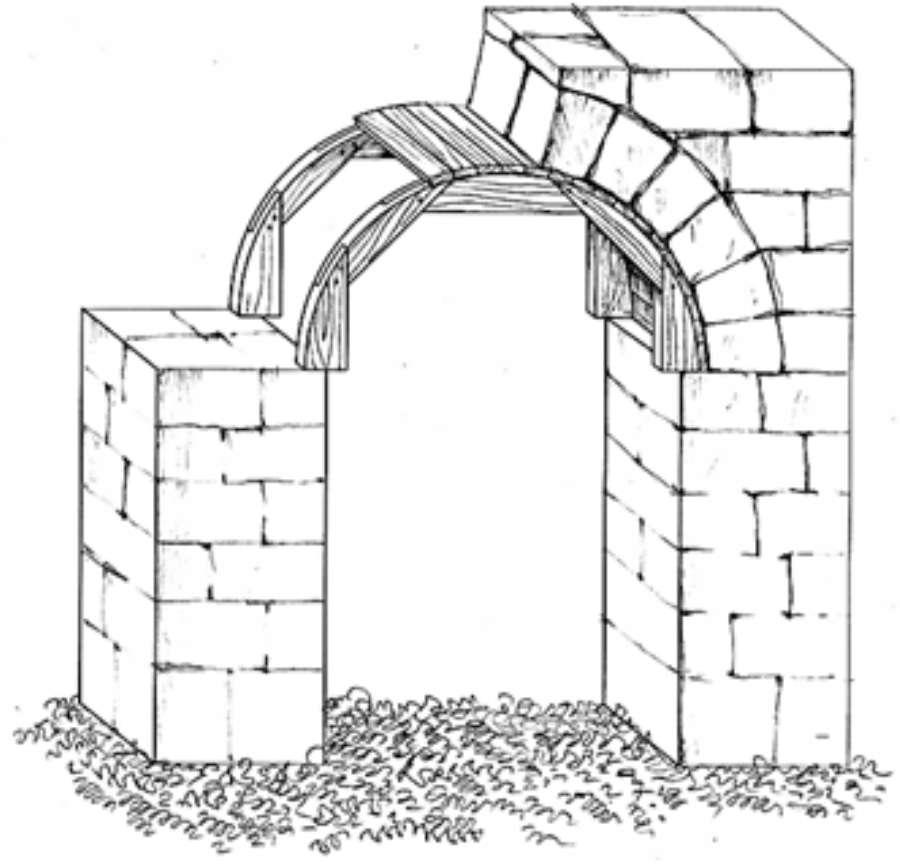

Iл. 42. Заощаджувана конструкція кружал, де замість дерев'яних стойок використані полиці в рівні п'яток арочних перемичок

По-третє: провести дослідження з метою пошуку історичних мап монастиря з зображенням планів прибудов до оборонних мурів на початковому етапі будівництва.

\section{References}

Kozyuba, V. K. (2012). Davn'orus'ke «stolpye» za istoryko-leksychnymy ta arxeolohichnymy materialamy. Arkheolohiya. 2, 42.

Kraynya, O. O. (2017). Vplyv militaryzatsiyi suspil'stva na zhyttya Tserkvy v Ukrayini (analiz dokumentiv z istoriyi Kyyevo-Pechers'koyi lavry 2-yi polovyny XVII - XVIII st.). Tserkva - nauka - suspil'stvo: pytannya vzayemodiyi. Materialy P'yatnadtsyatoyi Mizhnarodnoyi naukovoyi konferentsiyi (29 travnya - 3 chervnya 2017 r.). Kyiv.

Litopys Rus'kyj za Ipatiyivs'kym spyskom. (1989). Per. L. Maxnovec'. Kyiv: Dnipro.

Mal'chenko, O. (2017). Kyivs'kyj artylerijs'kyj arsenal u druhij polovyni XVII st. Kyiv: Akademperiodyka.

Pamyatniki gradostroitel'stva i arkhitektury Ukrainskoy SSR. T. 1 Kiev, Kievskaya oblast'. (1983). Kyiv: Budivel'nik.

Petrov, S. S. (2012). Oboronni sporudy Kyeva X-XIX st. u konteksti istoriyi mista i zahal'noho rozvytku viys'kovo-fortyfikatsiynoyi spravy. Kyiv: Ekspres-Polihraf.

Rappoport, P. A. (1956). Ocherki po istorii Russkogo voennogo zodchestva X-XIII vv. Moskva: Izdatel'stvo Akademii nauk SSSR, 120, ris. 90.

Sitkar'ova, O. V. (2005). Arkhitekturnyy ansambl' Kyevo-Pechers'koyi lavry ta yiyi istorychnoho otochennya za doby het'mana I. S. Mazepy. Kyiv: Dovira. 


\section{Lukjanchenko Vadym}

\section{SOME UNKNOWN FACTS OF THE EVOLUTION OF THE UP- PER LAVRA FORTIFICATIONS}

The research of the defensive structures of the Kyiv-Pechersk Lavra includes many important aspects requiring serious architectural, archaeological and bibliographic research. Among of them the question of the stages of their construction and the evolution of building. In the article is described assumption about the initial functional purpose of the premises of the South Tower, Onufriyivsky tower and Ivan Kashnikov tower, not only for the rifles firing during combat operations, but also for the guard of residence.

For the first time is presented reconstruction of some sections of the monastery walls and the Kashnikov tower in the initial construction period.

Key words: Kyiv-Pechersk Lavra, monastery walls. 